\title{
Antiviral activity of recombinant ankyrin targeted to the capsid domain of HIV-1 Gag polyprotein
}

\author{
Sawitree Nangola ${ }^{1,2,3}$, Agathe Urvoas $^{3}$, Marie Valerio-Lepiniec ${ }^{3}$, Wannisa Khamaikawin ${ }^{1,2}$, \\ Supachai Sakkhachornphop ${ }^{1,2}$, Saw-See Hong ${ }^{4,5}$, Pierre Boulanger ${ }^{4,5^{*}}$, Philippe Minard ${ }^{3^{*}}$ and \\ Chatchai Tayapiwatana ${ }^{1,2^{*}}$
}

\begin{abstract}
Background: Ankyrins are cellular mediators of a number of essential protein-protein interactions. Unlike intrabodies, ankyrins are composed of highly structured repeat modules characterized by disulfide bridgeindependent folding. Artificial ankyrin molecules, designed to target viral components, might act as intracellular antiviral agents and contribute to the cellular immunity against viral pathogens such as HIV-1.

Results: A phage-displayed library of artificial ankyrins was constructed, and screened on a polyprotein made of the fused matrix and capsid domains (MA-CA) of the HIV-1 Gag precursor. An ankyrin with three modules named Ank ${ }^{\mathrm{GAG}} 1 \mathrm{D} 4(16.5 \mathrm{kDa})$ was isolated. $\mathrm{Ank}^{\mathrm{GAG}} 1 \mathrm{D} 4$ and MA-CA formed a protein complex with a stoichiometry of 1:1 and a dissociation constant of $K_{d} \sim 1 \mu \mathrm{M}$, and the $A n k^{G A G} 1 D 4$ binding site was mapped to the N-terminal domain of the CA, within residues 1-110. HIV-1 production in SupT1 cells stably expressing Ank ${ }^{\mathrm{GAG}} 1 \mathrm{D} 4$ in both Nmyristoylated and non-N-myristoylated versions was significantly reduced compared to control cells. Ank ${ }^{\mathrm{GAG}} 1 \mathrm{D} 4$ expression also reduced the production of MLV, a phylogenetically distant retrovirus. The Ank ${ }^{G A G} 1 D 4-m e d i a t e d$ antiviral effect on HIV-1 was found to occur at post-integration steps, but did not involve the Gag precursor processing or cellular trafficking. Our data suggested that the lower HIV-1 progeny yields resulted from the negative interference of Ank ${ }^{G A G} 1 D 4-C A$ with the Gag assembly and budding pathway.

Conclusions: The resistance of Ank ${ }^{\mathrm{GAG}} 1 \mathrm{D} 4$-expressing cells to HIV-1 suggested that the CA-targeted ankyrin Ank ${ }^{\mathrm{GAG}} 1 \mathrm{D} 4$ could serve as a protein platform for the design of a novel class of intracellular inhibitors of HIV-1 assembly based on ankyrin-repeat modules.
\end{abstract}

Keywords: HIV-1, HIV-1 assembly, Gag polyprotein, CA domain, virus assembly inhibitor, ankyrins, artificial ankyrin library, intracellular antiviral agent

\section{Background}

In recent years, significant progress has been made in the control of HIV-1 infections using highly active antiretroviral therapy (HAART). Nevertheless, the occurrence of multi-drug resistant mutants and the side effects of HAART justify the exploration of alternative therapeutic approaches, such as gene therapy [1-5].

\footnotetext{
*Correspondence: pierre.boulanger@univ-lyon1.fr; philippe.minard@u-psud.fr; asimi002@hotmail.com

'Division of Clinical Immunology, Department of Medical Technology, Faculty of Associated Medical Sciences, Chiang Mai University, Chiang Mai, Thailand 50200

${ }^{3}$ Institut de Biochimie et de Biophysique Moléculaire et Cellulaire (IBBMC) UMR-8619, Université de Paris-Sud et CNRS, Orsay Cedex 91405, France Full list of author information is available at the end of the article
}

Several strategies for anti-HIV gene therapy are currently under development, and certain ones have been tested in hematopoietic cells [6-8]. They can be classified into two major categories: (i) RNA-based agents including antisense, ribozymes, aptamers and RNA interference [9]; (ii) protein-based agents including dominant-negative mutant proteins, intrabodies, intrakines, fusion inhibitors and zinc-finger nucleases [10,11]. The most commonly transduced genes with antiviral potential consist of those encoding derivatives of immunoglobulins. However, the complex structure of these molecules limits their antiviral function within cells, since their stability relies on disulfide bond(s) which

\section{Biomed Central}


rarely occur(s) in the reducing conditions of the intracellular milieu [12-16].

Several methods and novel molecules have been developed to overcome the limitations of antibodies and their derivatives (e.g. scFv), in terms of stability, facility of modifications, robustness, and cost-efficient production $[13,17-19]$. This is the case for molecules based on protein frameworks or scaffolds which interact with potential therapeutic targets by mimicking the binding process of immunoglobulins to their specific antigens. The ankyrin-repeat proteins represent an attractive scaffold to generate this type of specific binders $[20,21]$. Analysis of the protein sequence-structure relationship in natural ankyrins has defined consensus ankyrin motifs (or modules), and the results have been used to generate large libraries of artificial proteins, called 'Designed Ankyrin-Repeat Proteins' or DARPins. Several DARPins with desired binding specificity to various target molecules have successfully been isolated from such libraries [12,21-27], including competitors of HIV-1 binding to the viral receptor CD4 [28].

Ankyrins mediate many important protein-protein interactions in virtually all species and are found in all cellular compartments, indicating that these proteins can be adapted to function in a variety of environments, intracellular as well as extracellular [12,20,21,23,25,29,30]. For example, lentiviral vectors pseudotyped with HER2/neuspecific DARPins have been found to efficiently transduce their specific targets, HER2/neu-positive cells [31]. The major advantages of ankyrin-repeat proteins reside in (i) their binding specificity and affinity, as observed in DARPins selected from large libraries; (ii) their solubility and stability, even in the reducing conditions of the intracellular milieu; (iii) their sequence features present in DARPins, which are naturally expressed in human cells: as a consequence, ankyrin-repeat proteins are expected not to be as immunogenic as foreign proteins. Artificial ankyrins are therefore promising candidates as protein interfering reagents capable of acting both extra- and intra- cellularly [24].

In the present study, we designed artificial ankyrin molecules targeted to the HIV-1 Gag polyprotein and evaluated their potential as intracellular therapeutic agents which would negatively interfere with HIV-1 replication, and more specifically with the virus particle assembly machinery. To this aim, we constructed a library of ankyrin-repeat protein library expressed at the surface of recombinant filamentous bacteriophages. This phage-displayed library was screened on immobilized matrix (MA)-capsid (CA) domain (MA-CA) of the HIV$1 \mathrm{Gag}$ precursor (Pr55Gag, or more simply Gag), and a panel of Gag-specific artificial ankyrins were isolated. One particular Gag binder, Ank ${ }^{\mathrm{GAG}} 1 \mathrm{D} 4$, was selected for further characterization. Ank ${ }^{\mathrm{GAG}} 1 \mathrm{D} 4$ binding site was mapped to the $\mathrm{N}$-terminal domain of the CA, and SupT1 cells that stably expressed Ank ${ }^{\mathrm{GAG}} 1 \mathrm{D} 4$ showed a reduced permissiveness to HIV-1 infection. The Ank ${ }^{\mathrm{GAG}} 1 \mathrm{D} 4$-mediated antiviral effect was found to occur at post-integration steps of the HIV-1 life cycle involving the Gag protein assembly and budding machinery. This study demonstrated the potential of ankyrin-repeat proteins as a novel class of intracellular antivirals and suggested that $\mathrm{Ank}^{\mathrm{GAG}} 1 \mathrm{D} 4$ could serve as a protein platform for the design of efficient intracellular inhibitors of HIV-1 assembly.

\section{Results}

Design of artificial ankyrin-repeat motifs and construction of an ankyrin library

The construction of an artificial ankyrin library implies the randomization of amino acid residues localized on the accessible surface of ankyrin which has a potential interaction with the desired target, while maintaining intact the conserved residues of the consensus repeat modules which form the rigid framework of ankyrin. The consensus sequence of the ankyrin-repeat modules generated in this study was based on previous DARPins libraries [12-14,23,29,30,32], with minor modifications, as described in the Materials and Methods section. For example, the lysine residue (K) at position 25 was substituted for glutamate (E) to prevent a possible repulsion with the positively charged arginine (R) at position 21 (Tables 1 and Figure 1). Our ankyrin library was generated by randomization of amino acids at positions 2,3 , 5, 10, 13, and 14 (Figure 2 and 3). The amino acid side chains at these positions were all oriented outwards and belonged to the same surface-exposed surface of the ankyrin-repeat module (Figure 3B).

The artificial ankyrin-repeat proteins obtained were made of a variable number of ankyrin modules flanked by $\mathrm{N}$ - and $\mathrm{C}$-capping sequences $(\mathrm{N}$-cap and $\mathrm{C}$-cap; Figure 2B). The library was generated using the directional polymerization of one ankyrin microgene, each microgene corresponding to one single repeat motif. Polymerization was realized directly into a phagemid vector [33]. This resulted in proteins with variable numbers of repeats and sequence lengths. The length distribution in the library was determined by digesting the phagemid pool with restriction enzymes whose sites were located on both sides of the ankyrin coding sequence, followed by analysis of the DNA fragments by gel electrophoresis. A maximum number of 15 ankyrin repeats was obtained, and the most frequent numbers ranged from 1 to 6 .

Our final phage-displayed ankyrin library represented as many as $1.9 \times 10^{8}$ independent clones. The quality of our library was first evaluated by sequencing proteins from randomly picked clones. Nine out of fifteen clones $(60 \%)$ presented discontinuous sequences, with sequence 
Table 1 Randomization schemes used to introduce variability at specific positions of ankyrin repeats ${ }^{\text {(a) }}$

\begin{tabular}{ccc}
\hline Repeat position & Degenerated codons & Subset of encoded amino acid \\
\hline 2 & VDK, DMY, RAA & A, D, E, G, H, I, K, L, M, N, Q, R, S, T, V, Y \\
3 & VDK, DMY, VAN & $A, D, E, G, H, I, K, L, M, N, Q, R, S, T, V, Y$ \\
5 & VDK, DMY, VAN, TGG & $A, D, E, G, H, I, K, L, M, N, Q, R, S, T, V, W, Y$ \\
10 & $C T G, T G G, T A C, R T C$ & $I, L, V, W, Y$ \\
14 & KCK, TAC, CGY, VAR & $A, E, F, I, K, L, M, Q, R, S, Y$ \\
\hline
\end{tabular}

(a) For each position indicated on the leftmost column, the degenerated codons used for the microgene synthesis and the corresponding encoded amino-acids are indicated in the middle and rightmost columns, respectively. Standard letter for mixed bases refer to: $N=A / T / G / C, V=A / C / G, D=A / G / T, K=G / T, M=A / C, Y$ $=C / T, R=A / G$.

frameshifts and stop codons, which likely resulted from errors in oligonucleotide synthesis and/or assembly. Discontinuous sequences occurred with a higher frequency in ankyrins with numerous modules, while most ankyrin molecules with fewer repeats showed correct, open reading frames. The proportion of clones in our library with readthrough ankyrin sequences was also evaluated from the proportion of colonies which expressed C-terminally His-tagged soluble ankyrin protein: 34\% (24 out of 72 clones) were found to be positive for the C-terminal His- tag, as monitored by colony filtration blotting (COFI blot; data not shown). We therefore estimated the real diversity of our library to one third of the total number of independent clones, i.e. $6 \times 10^{7}$ independent ankyrin coding sequences.

\section{Production and purification of the viral protein target:} HIV-1 Gag precursor $\mathrm{H}_{6}$ MA-CA

The viral target used for screening our phage-displayed ankyrins consisted of the His-tagged recombinant

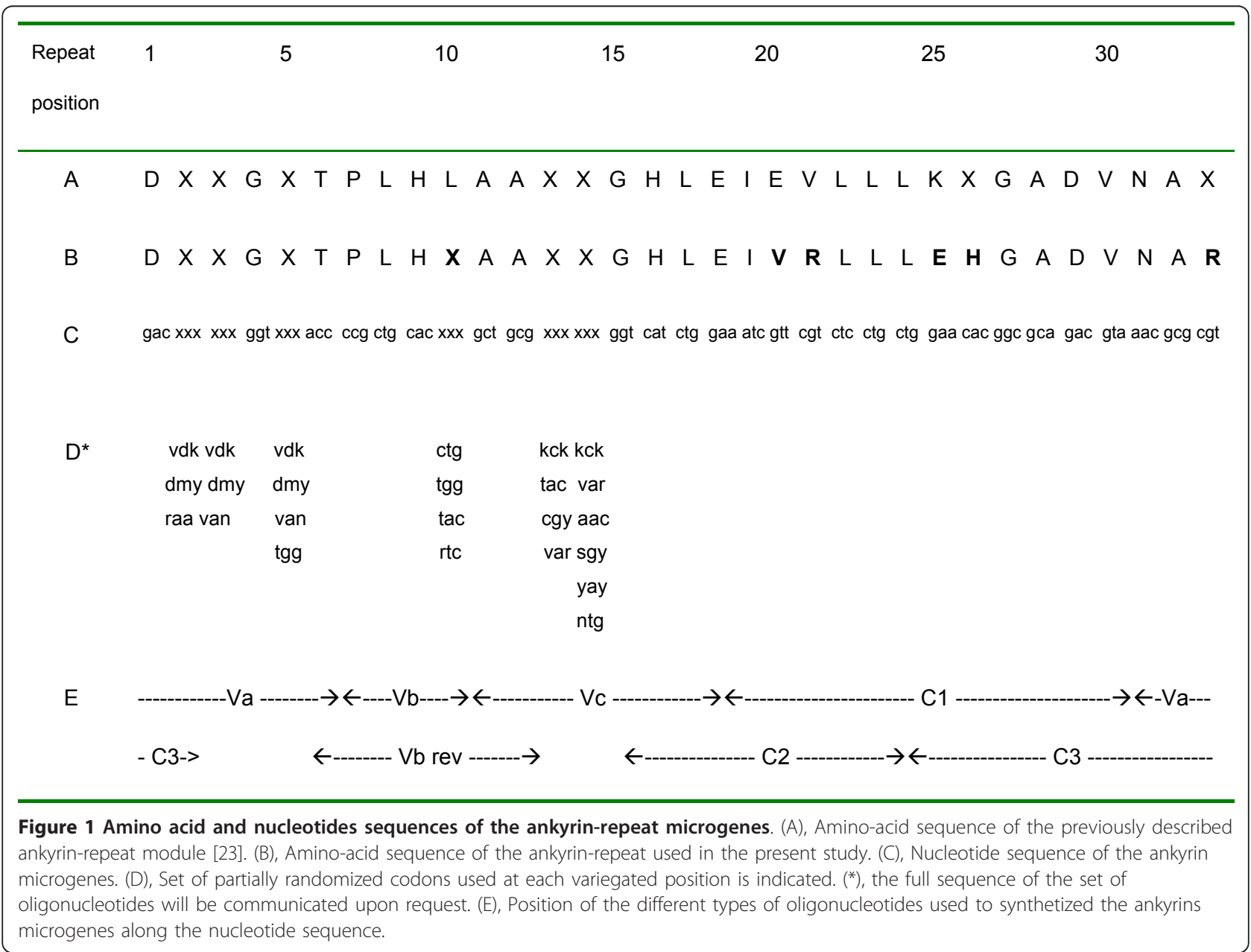




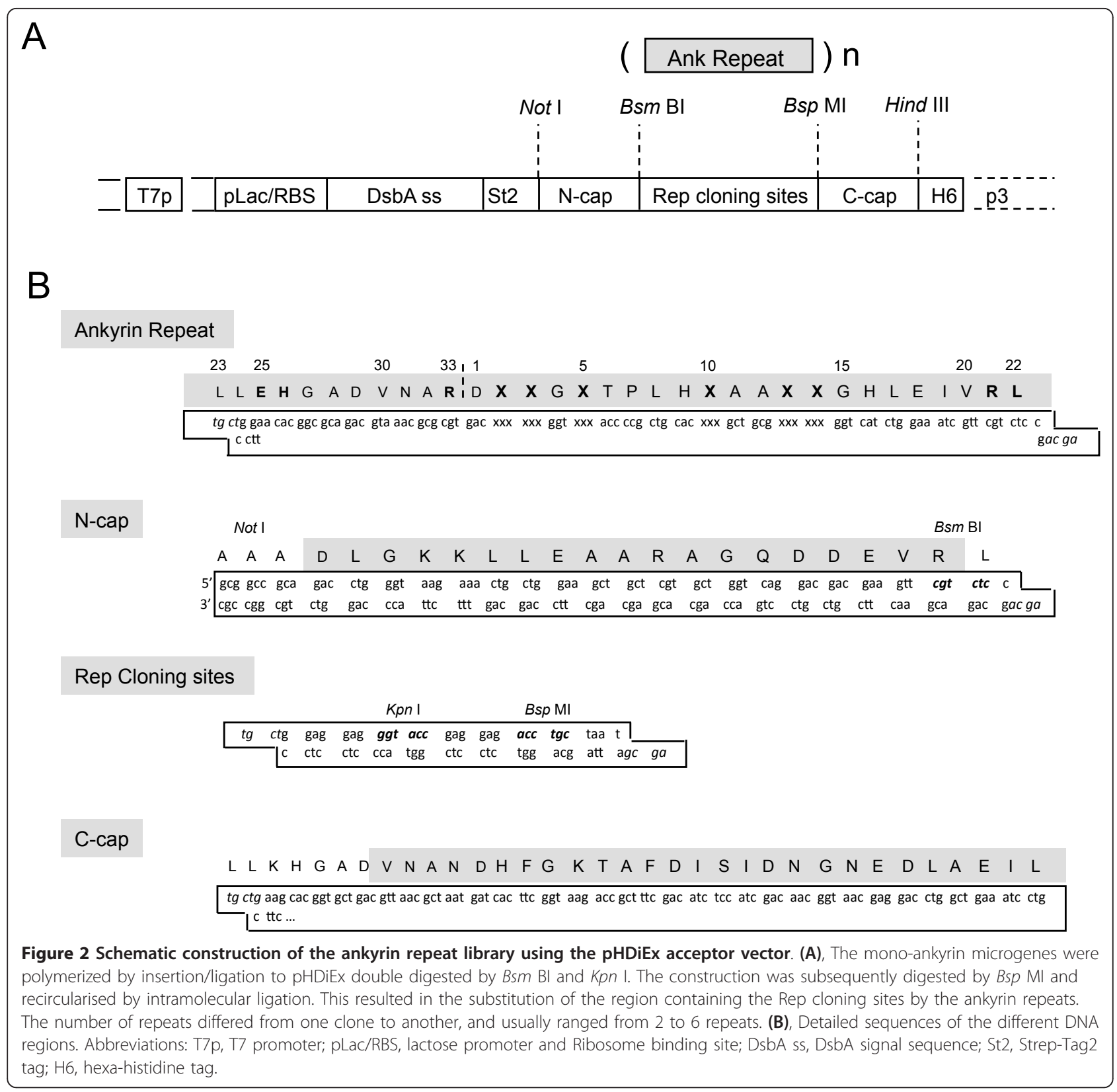

polyprotein $\mathrm{H}_{6} \mathrm{MA}-\mathrm{CA}$, corresponding to the MAp17 and CAp24 domains of the HIV-1 Gag precursor. The rationale for screening our ankyrin library on the MACA target was not only to search for MA- or/and CAbinders, but also for ankyrin(s) which recognize(s) the MAp17-CAp24 hinge region, which contains the cleavage site of the viral protease (PR). His-tagged recombinant protein $\mathrm{H}_{6} \mathrm{CA}$, which corresponded to the mature capsid protein CAp24, was used to identify the structural domains of the Gag precursor which contained the ankyrin-binding site. Large amounts of recombinant $\mathrm{H}_{6}$ MA-CA and $\mathrm{H}_{6}$ CA proteins were produced in Sf9 cells infected with recombinant baculoviruses BV-
$\mathrm{H}_{6} \mathrm{MA}-\mathrm{CA}$ or $\mathrm{BV}-\mathrm{H}_{6} \mathrm{CA}$, and the recombinant Gag proteins purified by affinity chromatography on nickelsepharose column.

\section{Screening of Gag-binding ankyrins using the phage- display method}

The phage-displayed library of ankyrins was amplified using a conventional protocol [34,35], and Gag-binders were isolated by three rounds of selection/elution from surface-immobilized $\mathrm{H}_{6} \mathrm{MA}-\mathrm{CA}$ protein. Elution of $\mathrm{H}_{6}$ MA-CA-bound phages was performed using acidic buffer for the first two rounds, followed by specific ligand elution using excess of soluble $\mathrm{H}_{6} \mathrm{MA}-\mathrm{CA}$ protein as the 


\section{A \\ 1--------10---------20---------30-33 \\ DARPin : DXXGXTPLHLAAXXGHLEIVEVLLKZGADVNAX}

\section{Library：DXXGXTPLHXAAXXGHLEIVRLLLEHGADVNAR}

B

C
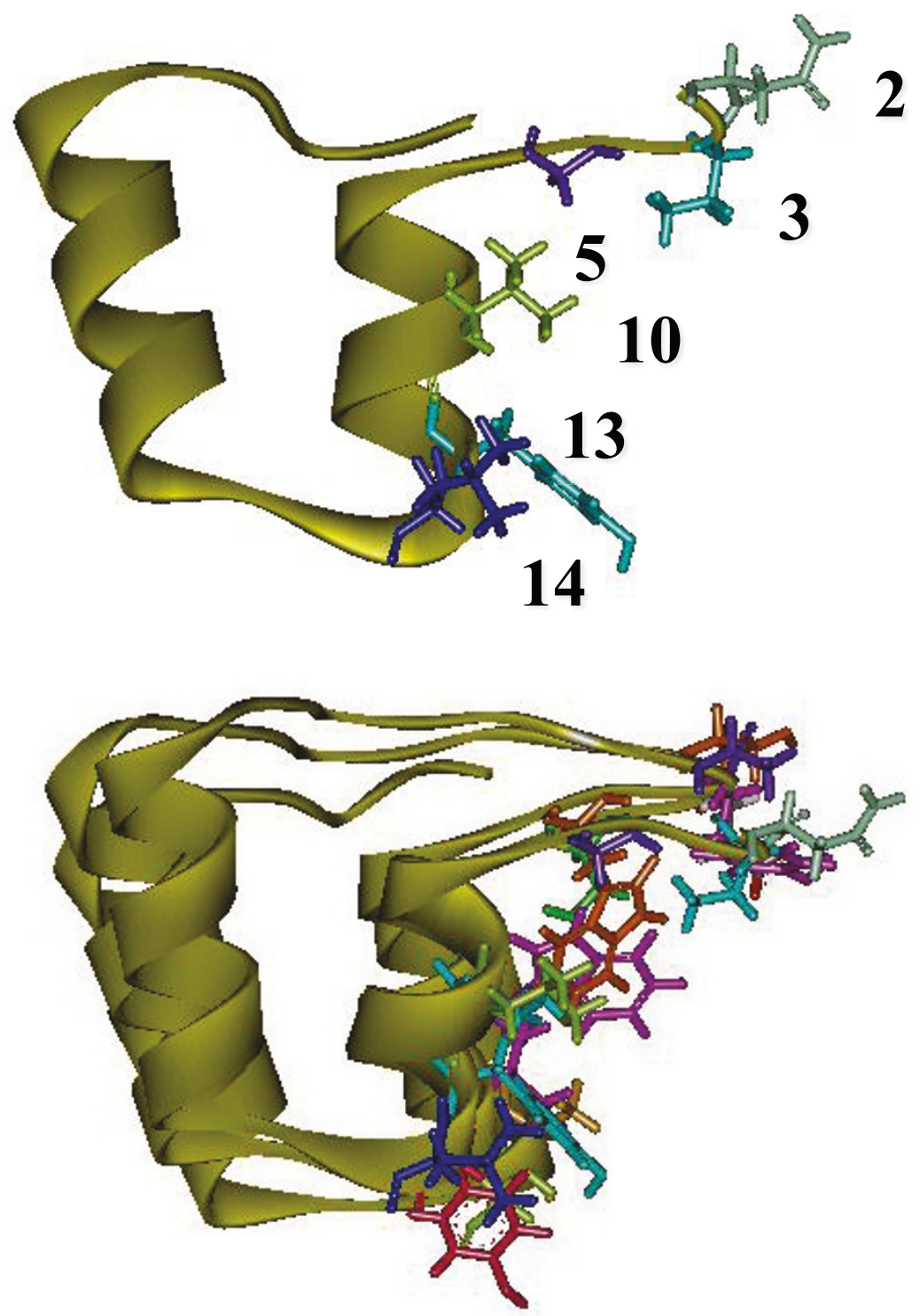

Figure 3 Consensus sequence and three-dimensional model of ankyrin module. (A), Sequence comparison between the consensus DARPin repeat motif and the repeat motif of our ankyrin library. The red letters refer to the positions of random amino acids, and blue letters represent the residues which differ from the consensus DARPin sequence. The position of the recognition site for the restriction nuclease Bsm BI is underlined. (B), Structural model of one single ankyrin repeat motif (or module). (C), Spatial arrangement of three modules belonging to the same ankyrin linear sequence (triple-repeat motif ankyrin molecule). The fixed structure of the repeat motif is presented as a yellow ribbon. The variable amino acids on the solvent-exposed surface are shown as stick pattern; their respective number in the linear sequence is indicated in panel B. 
competititor in the third round $[34,35]$. Phage clones were picked at random in each eluate, and tested by ELISA for binding to $\mathrm{H}_{6} \mathrm{MA}-\mathrm{CA}$. Only $20 \%$ of Gag-binders were found in the first eluate, whereas a significant enrichment was observed in the second and third eluates, with $70 \%$ of Gag-binders in both. Clones which gave a signal 5 -fold over the background signal were picked in all eluates and sequenced. All positive clones showed two or three ankyrin repeats flanked by $\mathrm{N}$-cap and C-cap. Three different clones, referred to as $\mathrm{Ank}^{\mathrm{GAG}} 1 \mathrm{~B} 8$, Ank ${ }^{\mathrm{GAG}} 1 \mathrm{D} 4$ and $\mathrm{Ank}^{\mathrm{GAG}} 6 \mathrm{~B} 4$ and containing three ankyrin modules each, were identified several times; they were therefore selected for further studies.

To evaluate the specificity of our Gag-binders, an irrelevant target protein, $\alpha$ Rep-A3, was used in lieu of $\mathrm{H}_{6}$ MA-CA. Protein $\alpha$ Rep-A3, previously described under the acronym $\alpha$ Rep-n 4 -a in our previous study [33], is an artificial alpha-helicoidal repeat protein ( $\alpha$ Rep) based on thermostable HEAT-like repeats, which folds cooperatively and shows a high stability [33]. Our phage-displayed ankyrin library was screened on immobilized $\alpha$ Rep-A3 protein, and $\alpha$ Rep-A3-bound clones were checked for binding specificity and sequenced. One ankyrin clone with a high affinity and specificity for the $\alpha$ Rep-A3 target, referred to as $\mathrm{Ank}^{\mathrm{A} 3} 2 \mathrm{D} 3$, was used as the irrelevant control of $\mathrm{H}_{6} \mathrm{MA}-\mathrm{CA}$ binders in the rest of the present study.

\section{Gag-ankyrin interaction}

Gag- and $\alpha$ Rep-A3-binding ankyrins were purified, chemically biotinylated, and assayed for their capacity of binding to their specific target in vitro. Importantly, no change was detected in the interaction of the three Gagbinders $\mathrm{Ank}^{\mathrm{GAG}} 1 \mathrm{~B} 8$, Ank ${ }^{\mathrm{GAG}} 1 \mathrm{D} 4$ and $\mathrm{Ank}^{\mathrm{GAG}} 6 \mathrm{~B} 4$, and of control $\alpha$ Rep-A3-binder $\mathrm{Ank}^{\mathrm{A} 3} 2 \mathrm{D} 3$, with their respective substrates, as determined by ELISA (data not shown). This indicated that biotinylation did not alter their Gag- or $\alpha$ Rep-A3-specific binding activity.

The degree of Gag-specificity of biotinylated Ank ${ }^{\mathrm{GAG}} 1 \mathrm{~B} 8$, Ank ${ }^{\mathrm{GAG}} 1 \mathrm{D} 4$ and $\mathrm{Ank}^{\mathrm{GAG}} 6 \mathrm{~B} 4$ was evaluated in the presence of specific or nonspecific competitors, and tested in ELISA using $\mathrm{H}_{6}$ MA-CA-coated wells. Controls consisted of $\mathrm{Ank}^{\mathrm{A} 3} 2 \mathrm{D} 3$ and $\alpha$ Rep-A3-coated wells. Competitors were (i) the same ankyrin protein in its non-biotinylated form and (ii) non-biotinylated $\alpha$ Rep-A3 protein. Ank ${ }^{\mathrm{GAG}} 1 \mathrm{~B} 8, \mathrm{Ank}^{\mathrm{GAG}} 1 \mathrm{D} 4, \mathrm{Ank}^{\mathrm{GAG}} 6 \mathrm{~B} 4$ and $\mathrm{Ank}^{\mathrm{A} 3} 2 \mathrm{D} 3$ were all competed with their respective nonbiotinylated versions, while no significant competition was observed between ankyrins $\mathrm{Ank}^{\mathrm{GAG}} 1 \mathrm{~B} 8, \mathrm{Ank}^{\mathrm{GAG}} 1 \mathrm{D} 4$, Ank ${ }^{\mathrm{GAG}} 6 \mathrm{~B} 4$ on one hand, and $\alpha$ Rep-A3 protein on the other hand (Figure 4A). Interestingly, $\mathrm{Ank}^{\mathrm{GAG}} 1 \mathrm{D} 4$ showed the highest signal of binding to the $\mathrm{H}_{6} \mathrm{MA}-\mathrm{CA}$ target, and the highest competition effect was observed with nonbiotinylated Ank ${ }^{\mathrm{GAG}} 1 \mathrm{D} 4$ (Figure $4 \mathrm{~A}$ ).

\section{Identification of the ankyrin binding domain on HIV-1 Gag precursor}

The structural domain of Pr55Gag recognized by each of the three Gag-binders Ank ${ }^{G A G} 1 B 8, A^{A n k}{ }^{G A G} 1 D 4$ and Ank ${ }^{\mathrm{GAG}} 6 \mathrm{~B} 4$ was determined by Far Western blot analysis and ELISA. Lysates of $\mathrm{H}_{6} \mathrm{MA}-\mathrm{CA}$-expressing Sf9 were analyzed by SDS-PAGE, and proteins transferred to PVDF membranes. Spontaneous cleavage of $\mathrm{H}_{6} \mathrm{MA}-\mathrm{CA}$ by insect cell proteases resulted in the occurrence of His-tagged $\mathrm{N}$-terminal domain, $\mathrm{H}_{6} \mathrm{MA}$, migrating as the mature matrix protein of the virion, MAp17 (Figure 4B; control, rightmost lane). All three Gag-binders, Ank ${ }^{G A G} 1 B 8, A n k{ }^{G A G} 1 D 4$ and Ank ${ }^{G A G} 6 B 4$, reacted with $\mathrm{H}_{6}$ MA-CA on blot, but not with $\mathrm{H}_{6} \mathrm{MA}$ (Figure $4 \mathrm{~B}$ ). This indicated that the ankyrin binding site was not located in the MA domain, but in the CA domain. As expected, no reaction was obtained with the control $\alpha$ Rep-A3-binder $\mathrm{Ank}^{\mathrm{A} 3} 2 \mathrm{D} 3$ (Figure 4B). The reactivity towards the CA domain was confirmed by indirect ELISA, using recombinant $\mathrm{H}_{6} \mathrm{CA}$ protein immobilized on nickel-coated wells. Positive signals with the CA protein were detected with all three Gag-binders, but not with $\mathrm{Ank}^{\mathrm{A} 3} 2 \mathrm{D} 3$ (Figure $4 \mathrm{C}$ ). This indicated that the binding sites of Ank ${ }^{\mathrm{GAG}} 1 \mathrm{~B} 8$, Ank ${ }^{\mathrm{GAG}} 1 \mathrm{D} 4$ and $\mathrm{Ank}^{\mathrm{GAG}} 6 \mathrm{~B} 4$ on $\mathrm{H}_{6} \mathrm{MA}-\mathrm{CA}$ protein were all situated in the CA domain.

\section{Biochemical characterization of Gag-binding ankyrins}

As shown in Figure $4 \mathrm{C}$, Ank ${ }^{\mathrm{GAG}} 1 \mathrm{~B} 8$ reacted with $\mathrm{H}_{6} \mathrm{CA}$ with the highest apparent affinity. However, DNA sequencing showed several nonconservative amino acid substitutions within the highly structured scaffold domain of the Ank ${ }^{\mathrm{GAG}} 1 \mathrm{~B} 8$ modules, as well as in $\mathrm{Ank}^{\mathrm{GAG}} 6 \mathrm{~B} 4$. Since these mutations could adversely affect the ankyrin-repeat motifs, Ank ${ }^{\mathrm{GAG}} 1 \mathrm{~B} 8$ and $A \mathrm{nk}^{\mathrm{GAG}} 6 \mathrm{~B} 4$ were excluded from our next analyses, and only Ank ${ }^{\mathrm{GAG}} 1 \mathrm{D} 4$ was selected for further characterization. DNA sequencing revealed that Ank ${ }^{\mathrm{GAG}} 1 \mathrm{D} 4$ protein comprised of three ankyrin modules, each containing different types of amino acids at the six assigned positions for variable residues (Figure 5A). The oligo-histidine tag allowed us to purify Ank ${ }^{\mathrm{GAG}} 1 \mathrm{D} 4$ protein to homogeneity by using a two-step chromatographic procedure, (i) affinity chromatography (Figure 5B, lane 3), and (ii) gel filtration (Figure 5B, lane 2). SDS-PAGE analysis showed that $\mathrm{Ank}^{\mathrm{GAG}} 1 \mathrm{D} 4$ migrated with an apparent molecular mass of $16.5 \mathrm{kDa}$ (Figure $5 \mathrm{~B}$ ), consistent with the theoretical mass $17.9 \mathrm{kDa}$ for a protein of 163 amino acid residues.

\section{Mapping of the Ank ${ }^{\mathrm{GAG}} 1 \mathrm{D} 4$ binding site on the CA domain}

A more refined mapping of the ankyrin binding site on the CA domain was performed using carboxyterminal deletion mutants of Gag expressed as recombinant proteins in baculovirus-infected cells. Gagamb276 and 


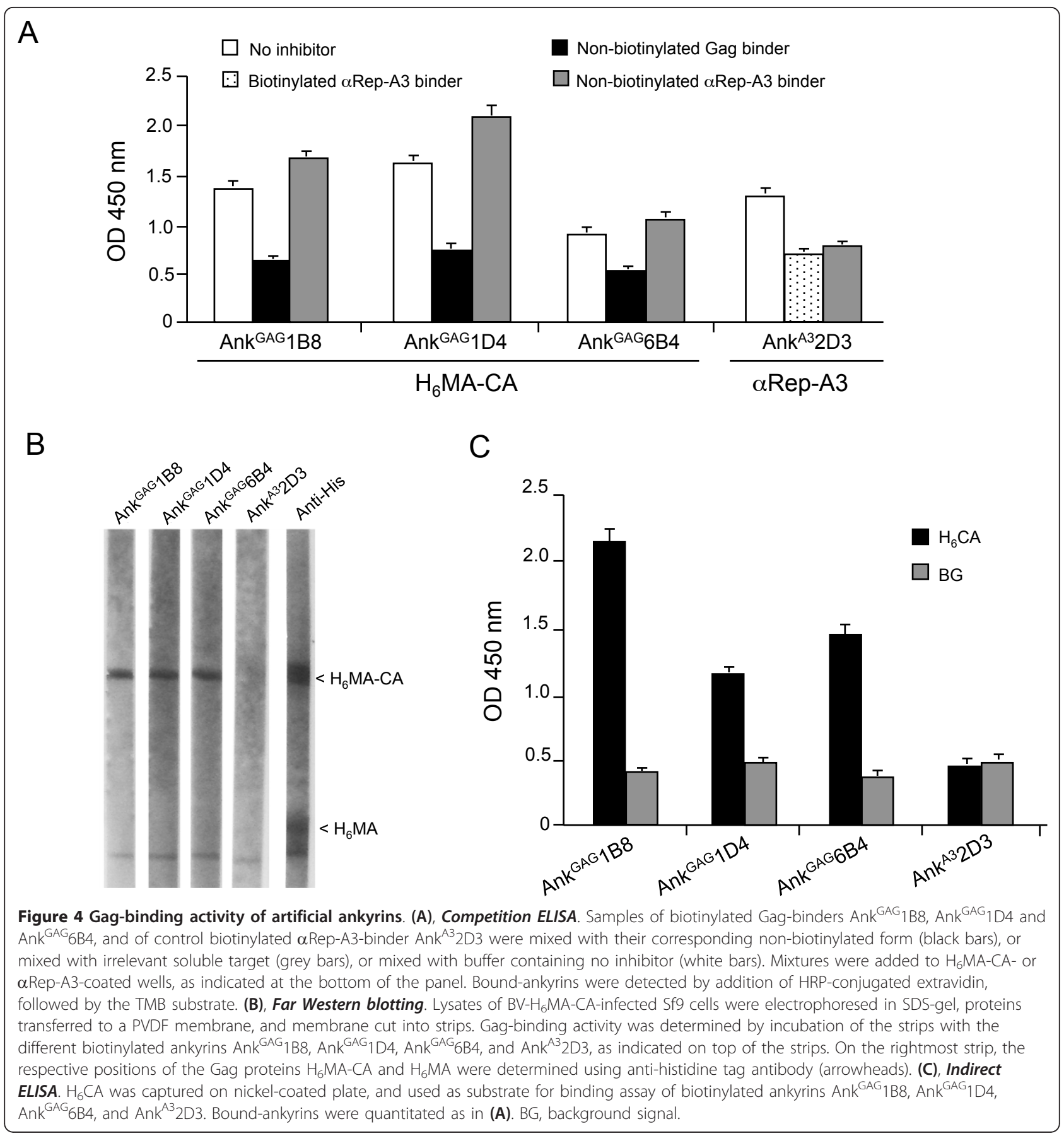

Gagamb241 mutants carried an amber stop codon in the Pr55Gag sequence at positions 276 and 241, respectively [36]. Both recombinant Gag proteins had in common the MA domain, plus 110 residues of the CA domain for Gagamb241, and 145 residues of the CA domain for Gagamb276 [36]. Ank ${ }^{\mathrm{GAG}} 1 \mathrm{D} 4$ was found to bind to both $\mathrm{C}$-truncated Gag proteins (Figure 6). This restricted the Ank ${ }^{\mathrm{GAG}} 1 \mathrm{D} 4$ binding site to the $\mathrm{N}$-terminal region of the $\mathrm{CA}$ domain spanning residues 1 to
110, corresponding to positions 132-241 in the Pr55Gag sequence of 500 amino acids.

\section{Gag-binding parameters of Ank ${ }^{\mathrm{GAG}} 1 \mathrm{D} 4$}

The specificity and binding parameters of Ank ${ }^{\mathrm{GAG}} 1 \mathrm{D} 4$ to its $\mathrm{H}_{6} \mathrm{MA}-\mathrm{CA}$ substrate were determined by microcalorimetry (ITC). Titration of increasing amounts of Ank ${ }^{\mathrm{GAG}} 1 \mathrm{D} 4$ protein into sample cell containing purified $\mathrm{H}_{6} \mathrm{MA}-\mathrm{CA}$ protein gave the approximate value of $1 \mu \mathrm{M}$ 
A

1-N-cap--

DLGKKLLEAARAGQDDEVRLLLEHGADVNAR

DS IGSTPLHLAAYYGHLE IVRLLLEHGADVNAR

1

DSTGTTPLHYAARLGHLE IVRLLLEHGADVNAR

DAMGWTPLHLAAKKGHLE IVRLLLKHGADVNAN

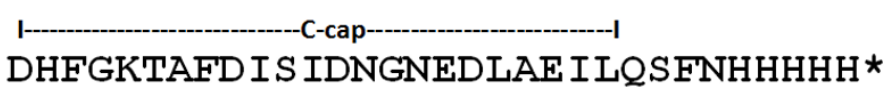

B

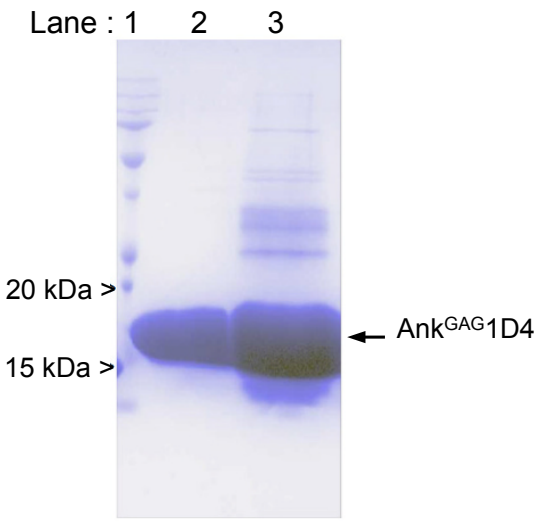

Figure 5 Characterization of Ank ${ }^{\mathrm{GAG}} 1 \mathrm{D} 4$. (A), Amino acid sequence of the $\mathrm{Ank}^{\mathrm{GAG}} 1 \mathrm{D} 4$ protein, represented by using the single letter code. The variable residues at the six predefined positions on the ankyrin solvent-exposed surface were highlighted in red. (B), SDS-PAGE analysis of $A n k^{G A G} 1 D 4$. The Ank ${ }^{G A G} 1 D 4$ protein was first isolated by affinity chromatography on nickel-column (HisTrap column; lane 3), and further purified by gel filtration chromatography (Sephadex G-75 column; lane 2). Lane 1, molecular mass markers.

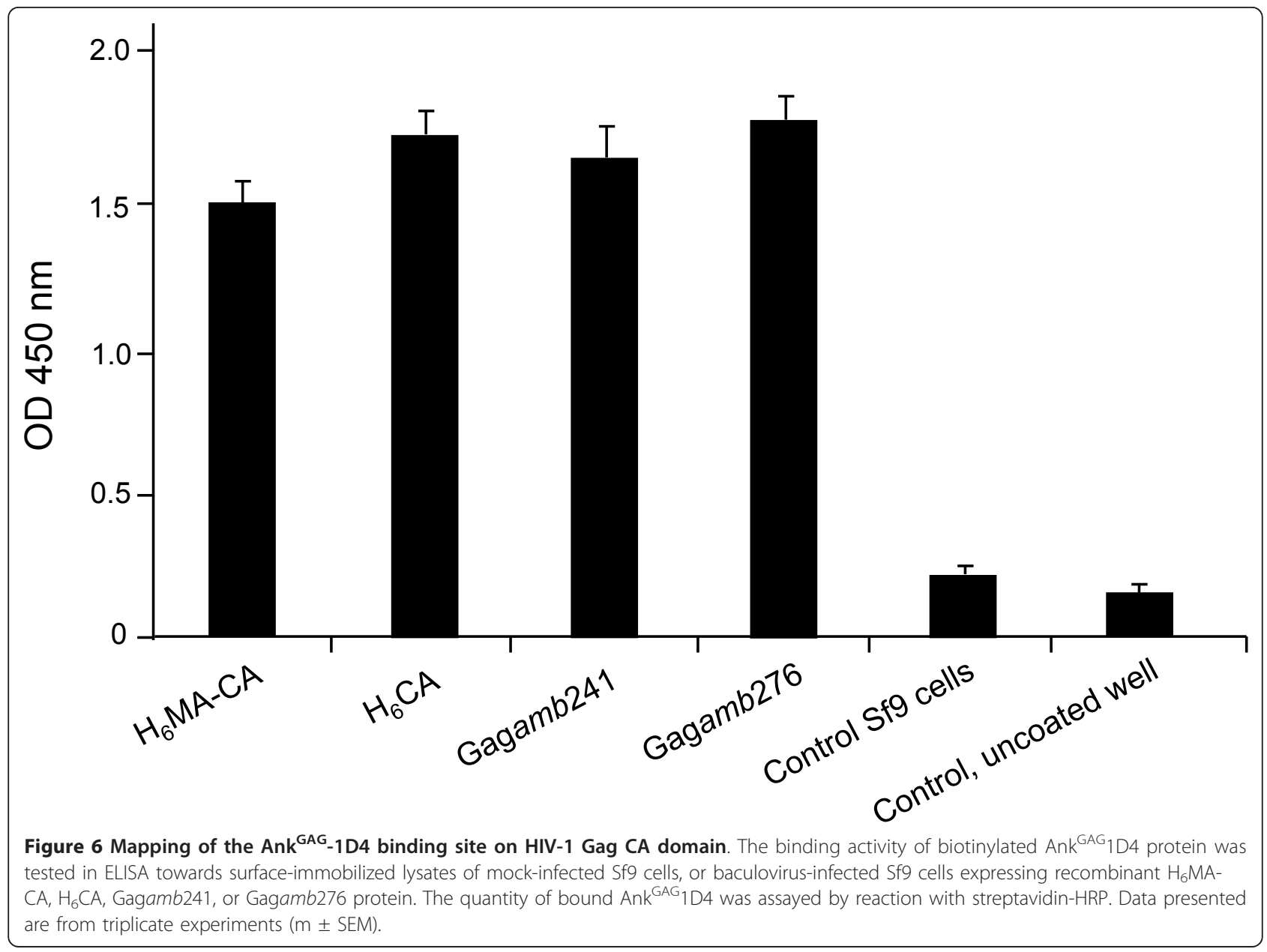


for the dissociation constant $\left(K_{\mathrm{d}}\right)$ of the specific reaction of the binder with its target protein (Figure 7; leftmost top panel). In control experiments, no interaction was detected between Ank ${ }^{\mathrm{GAG}} 1 \mathrm{D} 4$ and $\alpha$ Rep-A3 (Figure 7; middle top panel). By comparison, Ank ${ }^{\mathrm{A} 3} 2 \mathrm{D} 3$ interacted with its substrate $\alpha$ Rep-A3 with a $K_{\mathrm{d}}=18 \mathrm{nM}$ (Figure 7; rightmost top panel).

The stoichiometry $(\mathrm{N})$ of the interacting molecules in the protein complexes and the number of binding sites were calculated from the fitting curves of ITC data. The stoichiometry of protein monomers was found to be $\mathrm{N}$ $=0.91$ for the pair $\mathrm{Ank}^{\mathrm{GAG}} 1 \mathrm{D} 4 / \mathrm{H}_{6} \mathrm{MA}-\mathrm{CA}$, and $\mathrm{N}=$ 0.62 for the control pair Ank ${ }^{\mathrm{A} 3} 2 \mathrm{D} 3 / \alpha$ Rep-A3 (Figure 7). The $\alpha$ Rep-A3 protein is known to occur as a homodimer [33], and the experimental value of 0.62 was close to the theoretical ratio of 0.5 . The data therefore suggested that one molecule of $\mathrm{Ank}^{\mathrm{A} 3} 2 \mathrm{D} 3$ bound to an $\alpha$ Rep-A3 homodimer to form a ternary $\mathrm{Ank}^{\mathrm{A} 3}$ 2D3/ $(\alpha \text { Rep-A3) })_{2}$ complex. By contrast, Ank ${ }^{\mathrm{GAG}} 1 \mathrm{D} 4$ bound to the $\mathrm{H}_{6} \mathrm{MA}-\mathrm{CA}$ monomer in a 1-to-1 binary complex.

\section{Construction of SupT1 cell lines stably expressing Gag-} binding ankyrin proteins

Two pCEP4-based episomal plasmids encoding the Ank ${ }^{\mathrm{GAG}} 1 \mathrm{D} 4$ protein in its $\mathrm{Myr}+$ and Myr0 versions, respectively, and fused to His-tagged GFP at the N-terminus (Figure 8A) were transfected into the SupT1 cell line. Clones that stably expressed Ank ${ }^{\mathrm{GAG}} 1 \mathrm{D} 4$-GFP protein (SupT1/Myr+Ank ${ }^{\text {GAG }}$ 1D4-GFP and SupT1/Myr0Ank${ }_{\text {GAG }} 1 \mathrm{D} 4-\mathrm{GFP}$ ) were identified by fluorescent microscopy, isolated and expanded under the hygromycin-B selection. Two control SupT1 cell lines harboring the pCEP4 plasmids encoding the Myr+ and Myr0 versions of Gag-irrelevant $\mathrm{Ank}^{\mathrm{A} 3}$ 2D3-GFP (SupT1/Myr+Ank ${ }^{\mathrm{A} 3} 2 \mathrm{D} 3-$ GFP and SupT1/Myr0Ank ${ }^{\mathrm{A3}} 2 \mathrm{D} 3$-GFP) were generated in parallel. Confocal microscopy showed that Myr+Ank ${ }^{\mathrm{GAG}} 1 \mathrm{D} 4-\mathrm{GFP}$ and $\mathrm{Myr}+\mathrm{Ank}^{\mathrm{A} 3}$ 2D3-GFP localized in both the cytoplasm and the plasma membrane, as expected for $\mathrm{N}$-myristoylated proteins, whereas Myr0Ank ${ }^{\mathrm{GAG}} 1 \mathrm{D} 4-\mathrm{GFP}$ and Myr0Ank ${ }^{\mathrm{A} 3}$ 2D3-GFP showed a diffuse cytoplasmic fluorescence. Flow cytometry analysis showed that almost $80 \%$ of ankyrin-expressing cells were GFP-positive, and that Myr+Ank ${ }^{\mathrm{GAG}} 1 \mathrm{D} 4-\mathrm{GFP}$ or Myr0Ank ${ }^{\mathrm{GAG}} 1 \mathrm{D} 4-\mathrm{GFP}$ did not negatively interfere with the surface expression of CD4 (Figure 8B). The status of CD4 molecules, the primary receptors of HIV-1, was important to assess in ankyrinexpressing cells prior to HIV-1 infection, in order to ensure that SupT1/Myr+Ank ${ }^{\mathrm{GAG}} 1 \mathrm{D} 4-\mathrm{GFP}$ and SupT1/ Myr0Ank ${ }^{\mathrm{GAG}} 1 \mathrm{D} 4-\mathrm{GFP}$ cells could serve as host cells for testing the functionality of $\mathrm{Ank}^{\mathrm{GAG}} 1 \mathrm{D} 4$ as antiviral agent.

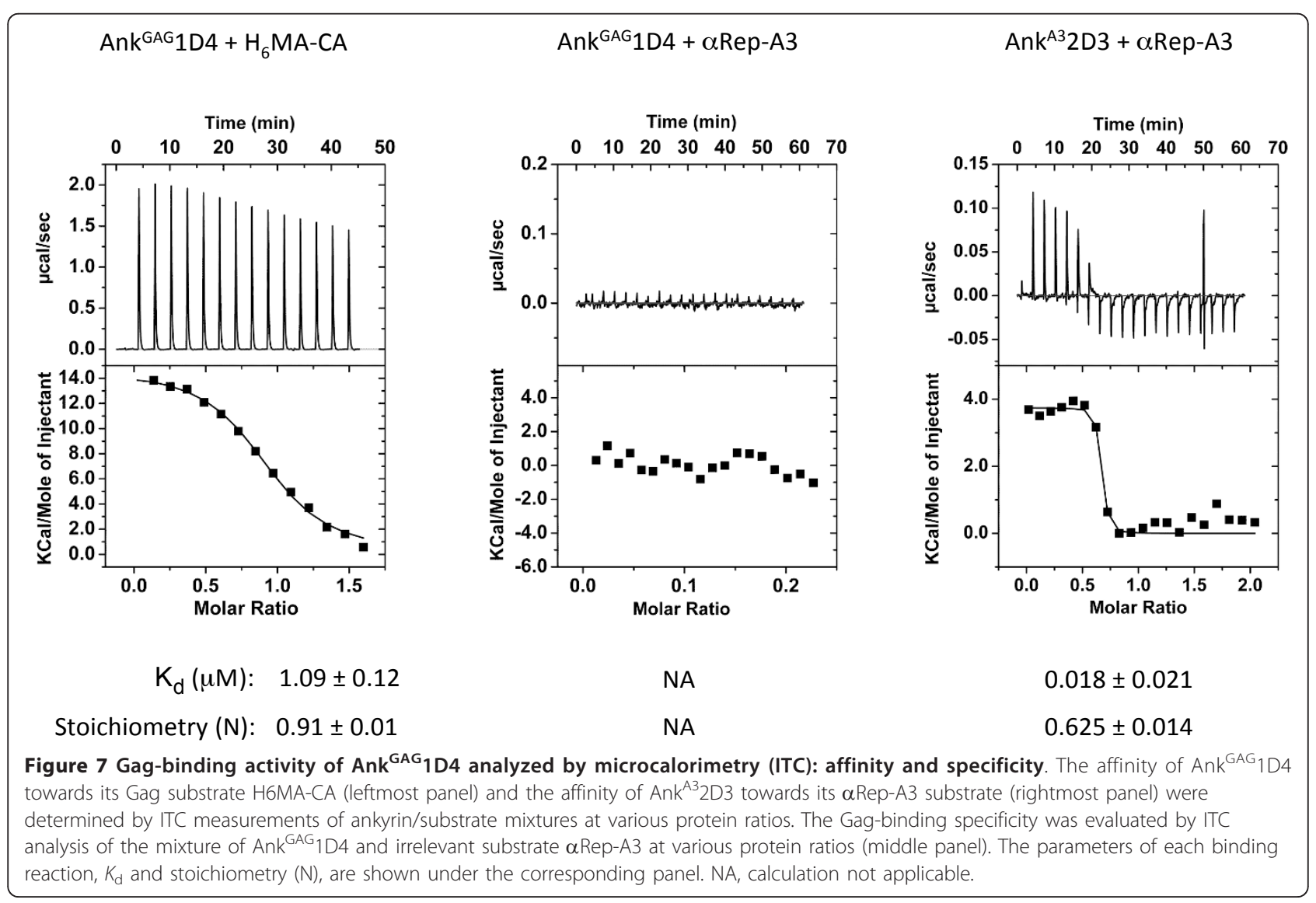


A

(a) pCEP4-Myr+Ank ${ }^{G A G} 1 D 4-G F P$

Myr

I

MGSSKSK-

GFP

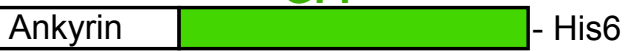

(b) pCEP4-Myr0Ank ${ }^{G A G} 1 D 4-G F P$

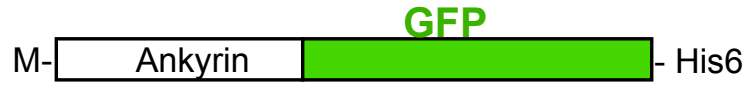

B

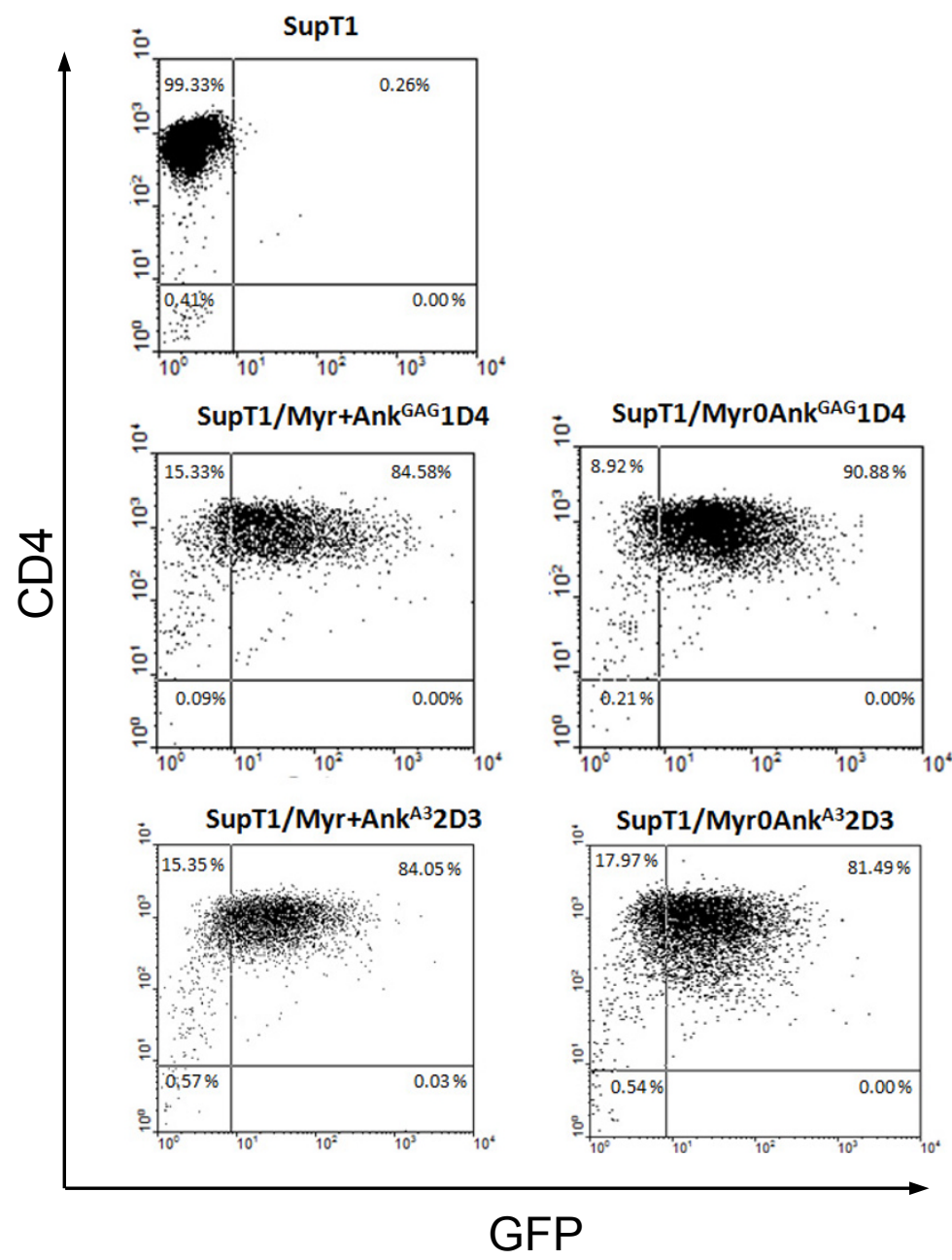

Figure 8 Characterization of SupT1 cells stably expressing artificial ankyrins. (A), Ankyrin constructs. Schematic representation of the artificial ankyrin constructs designed for stable expression in SupT1 cells, using pCEP4-based vector. Histidine-tag and green fluorescence protein (GFP; green box) were inserted at the C-terminus and in-phase with the ankyrin sequence (white box). Addition of a N-myristoylation signal (in purple red letters) to the Myr+Ank ${ }^{G A G} 1 D 4-G F P$ clone resulted in the removal of the N-terminal methionine (M) and covalent linkage of myristic acid chain (Myr; in blue letters) to glycine-2 (G). (B), Flow cytometry. Expression of CD4 molecules at the surface of control SupT1 cells, SupT1/ Myr+Ank ${ }^{\text {GAG }} 1$ D4-GFP and SupT1/MyrOAnk ${ }^{\text {GAG }} 1$ D4-GFP cells. Flow cytometry analysis was performed on nonpermeabilized cells, using monoclonal antibody against CD4, followed by PE-conjugated goat anti-mouse lgG. 
HIV-1 infection of ankyrin-expressing SupT1 cell lines SupT1/Myr+Ank ${ }^{\text {GAG }} 1 \mathrm{D} 4-$ GFP, SupT1/Myr0Ank${ }^{G A G} 1 D 4-G F P$, SupT1/Myr+Ank ${ }^{A 3} 2 D 3-G F P$ and SupT1/ Myr0Ank ${ }^{\mathrm{A} 3}$ 2D3-GFP cells were infected with HIV-1 ${ }_{\mathrm{NL4}-3}$ virus at MOI 10 for $16 \mathrm{~h}$ at $37^{\circ} \mathrm{C}$. Cells were harvested at day 11 post-infection (pi), and examined in confocal microscopy after permeabilization and reaction with antiCAp24 mAb and PE-conjugated anti-mouse IgG-F(ab') ${ }_{2}$ antibody. In infected cells expressing Myr+Ank ${ }^{\mathrm{GAG}} 1 \mathrm{D} 4$ GFP, the Gag and GFP signals superimposed in both cytoplasmic compartment and at the plasma membrane, as expected for two $\mathrm{N}$-myristoylated, membrane-targeted partner proteins (Figure 9a). Gag and Gag-irrelevant $\mathrm{N}$-myristoylated ankyrin $\mathrm{Myr}+\mathrm{Ank}^{\mathrm{A3}}$ 2D3-GFP were also both addressed to the plasma membrane, but showed a lesser degree of colocalization (Figure 9c). No significant colocalization was detected for Gag and the non-N-myristoylated, Gag-irrelevant ankyrin Myr0Ank ${ }^{\mathrm{A} 3} 2 \mathrm{D} 3-\mathrm{GFP}$ (Figure 9d). Interestingly, a significant degree of colocalization was observed for Gag and the non- $\mathrm{N}$-myristoylated Gag-binder Myr0Ank ${ }^{\text {GAG }} 1$ D4-GFP (Figure 9b). This implied that Gag and Myr0Ank ${ }^{\mathrm{GAG}} 1 \mathrm{D} 4$-GFP proteins interacted within the cytoplasm and were addressed as a complex to the plasma membrane, via the N-myristoylated signal carried by the Gag protein partner.

\section{Negative effect of Ank ${ }^{\mathrm{GAG}} 1 \mathrm{D} 4$ on HIV-1 production}

The possible antiviral activity of Ank ${ }^{\mathrm{GAG}} 1 \mathrm{D} 4$ on HIV-1 assembly and budding was first evaluated by syncytium formation. SupT1 cells expressing Myr+Ank ${ }^{\mathrm{GAG}} 1 \mathrm{D} 4-\mathrm{GFP}$, Myr0Ank ${ }^{\text {GAG }}$ 1D4-GFP, Myr+Ank ${ }^{\mathrm{A3}}$ 2D3-GFP and Myr0$\mathrm{Ank}^{\mathrm{A} 3}$ 2D3-GFP, respectively, were infected with HIV$1_{\mathrm{NL} 4-3}$ virus at MOI 10 for $16 \mathrm{~h}$ at $37^{\circ} \mathrm{C}$, and examined by phase contrast microscopy at day 11 pi. Numerous syncytia were observed in control samples of HIV-1-infected SupT1 cells (Figure 10, upper row) as well as in HIV-1infected SupT1/Myr+Ank ${ }^{\mathrm{A} 3} 2 \mathrm{D} 3$ and SupT1/Myr0An$\mathrm{k}^{\mathrm{A3}} 2 \mathrm{D} 3$ cells (Figure 10, two bottom rows). However, very few syncytia were observed in HIV-1-infected SupT1/ Myr0Ank ${ }^{\mathrm{GAG}} 1 \mathrm{D} 4$ cells (Figure 10, third row from the top), and very rare, if any, in HIV-1-infected SupT1/Myr+Ank ${ }^{\mathrm{GAG}} 1 \mathrm{D} 4$ cells (Figure 10, second row from the top).

Virus yields were quantitated in the extracellular medium of ankyrin-expressing SupT1 cells infected with HIV- $1_{\text {NL4-3 }}$ virus, in the same conditions as above. Culture supernatants were collected at different times pi, and virus progeny titer indirectly determined using ELISA/CAp24. A significant reduction of extracellular levels of CAp24 was observed at days 11 and $13 \mathrm{pi}$ in the supernatants of SupT1/Myr+Ank ${ }^{\text {GAG }} 1 \mathrm{D} 4-$ GFP and SupT1/Myr0Ank ${ }^{\mathrm{GAG}} 1 \mathrm{D} 4-\mathrm{GFP}$ cells, compared to control cells, nontransduced HIV-1-infected SupT1 cells and SupT1 cells expressing the Gag-irrelevant ankyrin Myr $+\mathrm{Ank}^{\mathrm{A} 3}$ 2D3-GFP (Figure 11A). There was a slight decrease of CAp24 levels in the culture medium of SupT1/Myr+Ank ${ }^{\mathrm{A} 3}$ 2D3-GFP, compared to control SupT1 cells, and this effect was less pronounced in SupT1/Myr0Ank ${ }^{\mathrm{A} 3}$ 2D3-GFP cells, which expressed a Gag-irrelevant, non-N-myristoylated ankyrin, (Figure 11A). The possibility that the increase in CAp24 yields at day 13 pi might be due to Ank ${ }^{\mathrm{GAG}} 1 \mathrm{D} 4$-escape HIV-1 mutant(s) was investigated: no mutation in the gag gene was found in RT-PCR amplicons derived from the HIV-1 progeny of SupT1/Myr+Ank ${ }^{\mathrm{GAG}} 1 \mathrm{D} 4$ cells harvested at day 13 . However, this did not exclude that $\mathrm{Ank}^{\mathrm{GAG}} 1 \mathrm{D} 4-$ resistant gag mutants could be found after a higher number of passages. Long-term cultures of HIV-1-infected SupT1 cells stably expressing Ank ${ }^{\mathrm{GAG}} 1 \mathrm{D} 4$ will be necessary to evaluate the viral genetic barrier to $\mathrm{Ank}^{\mathrm{GAG}} 1 \mathrm{D} 4$.

Viral loads were also determined at day-11 in the extracellular media, and the data confirmed the ELISA/CAp24. A significant inhibitory effect of $\mathrm{Myr}+\mathrm{Ank}^{\mathrm{GAG}} 1 \mathrm{D} 4$ on HIV-1 replication was observed, with an average 600-fold lower virus progeny production, compared to control, nontransduced HIV-1-infected SupT1 cells $\left(2,500 \times 10^{7}\right.$ genome copies/mL; Figure 11B). A significant decrease in HIV-1 production was also observed with the non-N-myristoylated ankyrin Myr0Ank ${ }^{\mathrm{GAG}} 1 \mathrm{D} 4$, although to a lesser degree compared to its $\mathrm{N}$-myristoylated version (160-fold less; Figure 11B). These results indicated that the antiviral function of Ank ${ }^{\mathrm{GAG}} 1 \mathrm{D} 4$ occurred in both compartments, plasma membrane and cytoplasm, but with a higher efficiency when the ankyrin molecules were addressed to the plasma membrane (Figure 11B). This suggested that the antiviral function carried by Ank ${ }^{\mathrm{GAG}} 1 \mathrm{D} 4$ occurred at late step(s) of the virus life cycle, e.g. the assembly and budding of virus particles. As observed in ELISA/CAp24, SupT1 cells expressing Gag-irrelevant, N-myristoylated ankyrin molecule Myr+Ank ${ }^{\mathrm{A} 3}$ 2D3-GFP showed some decrease $(17$-fold $)$ in virus production $\left(140 \times 10^{7}\right.$ genome copies/ $\mathrm{mL}$; Figure 11B).

\section{Ank ${ }^{\mathrm{GAG}}$ 1D4-mediated antiviral activity in HIV-1 life cycle: early versus late step(s)}

As a partner of the HIV-1 structural protein CAp24, Ank ${ }^{\mathrm{GAG}} 1 \mathrm{D} 4$ might interfere with various step(s) of the HIV-1 life cycle. This included (i) virus uncoating, (ii) intracellular trafficking of incoming viruses, (iii) nuclear import of the viral preintegration complex, at early times, (iv) Gag oligomerisation, (v) virus particle assembly, and (v) extracellular budding, at late times post infection. To address this issue, integration events were evaluated by PCR amplification of Alu-gag junctions in HIV-1-infected, Ank ${ }^{\mathrm{GAG}} 1 \mathrm{D} 4$-expressing SupT1 cells harvested at day 11 pi. Control samples consisted of HIV-1-infected, nontransfected SupT1 cells and SupT1 cells expressing Gag-irrelevant, $\mathrm{Ank}^{\mathrm{A} 3} 2 \mathrm{D} 3$ ankyrin. There was no significant difference between Ank ${ }^{\mathrm{GAG}} 1 \mathrm{D} 4$-expressing SupT1 cells 


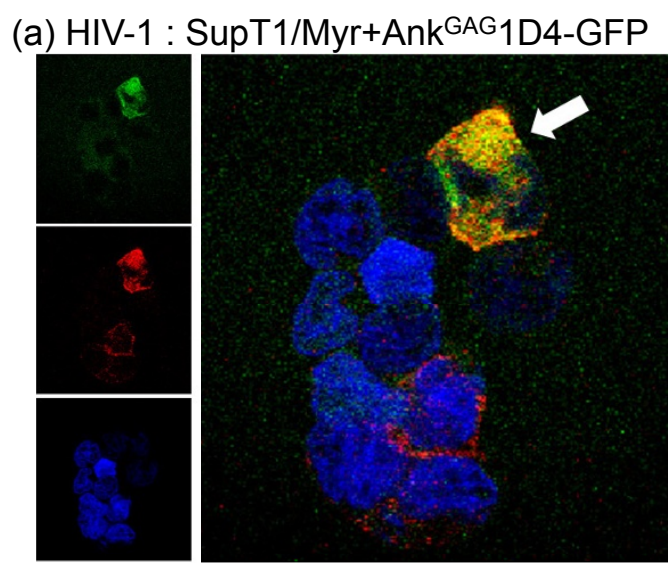

$\mathrm{R}=0.855$

(c) HIV-1 : SupT1/Myr+AnkA32D3-GFP
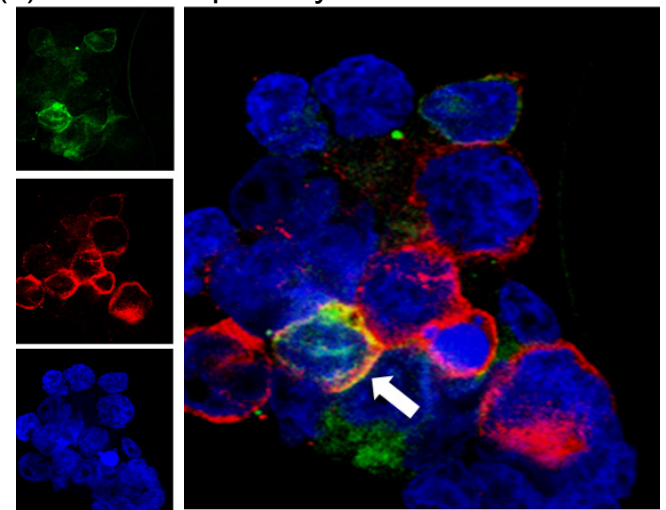

$R=0.757$ (b) HIV-1 : SupT1/MyrOAnk ${ }^{\text {GAG1D4-GFP }}$
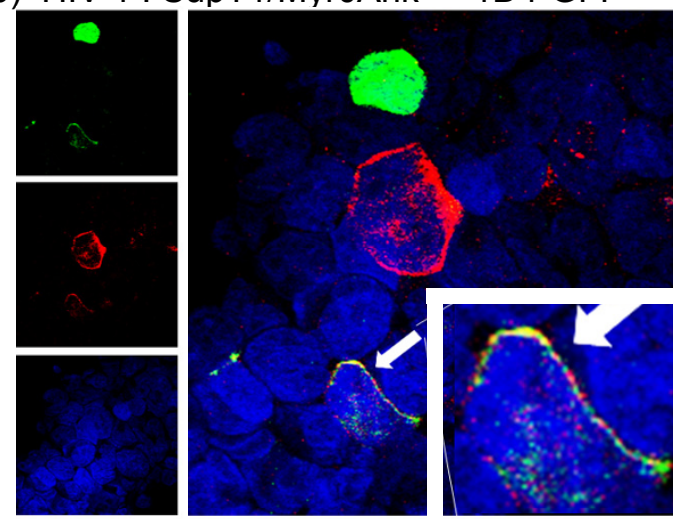

$R=0.815$

(d) HIV-1 : SupT1/MyrOAnk'A32D3-GFP
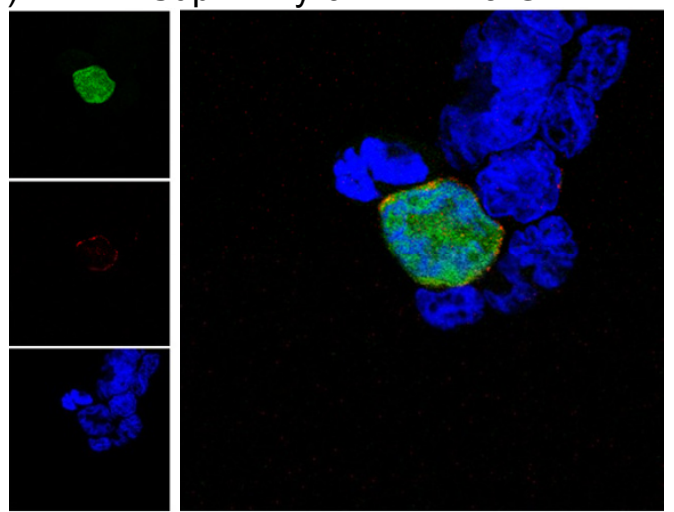

$\mathrm{R}=0.115$

Figure 9 Confocal microscopy of HIV-1-infected, ankyrin-expressing SupT1 cells. HIV-1-infected SupT1/Myr+Ank ${ }^{\text {GAG }} 1$ D4-GFP (panel a), SupT1/MyrOAnk ${ }^{\mathrm{GAG}} 1 \mathrm{D} 4-\mathrm{GFP}$ (b), SupT1/Myr+Ank ${ }^{\mathrm{A} 3} 2 \mathrm{D} 3-\mathrm{GFP}$ (c), and SupT1/MyrOAnk ${ }^{\mathrm{A} 3} 2 \mathrm{D} 3-\mathrm{GFP}$ cells (d) were collected at day 11 pi,

permeabilized, immunolabeled with anti-CAp24 mAb and PE-conjugated anti-mouse IgG F(ab') 2 antibody (red signal), and nuclei counter-stained in blue with DAPI. Ankyrins were detected by their GFP-tag. Merged images are enlarged and shown on the right side of each panel. White arrows point to cells showing colocalization of ankyrin and Gag proteins. R, the Pearson correlation coefficient for signal colocalization, was determined using the Olympus FluoView software.

and control cells (Table 2), suggesting that the Ank ${ }^{\mathrm{GAG}} 1 \mathrm{D} 4$-mediated antiviral effect took place at the post-integration phase of the virus life cycle. To validate this negative result, control experiments of integration blockage were carried out using the HIV-1 integrase inhibitor Raltegravir ${ }^{\mathrm{TM}}$ (RAL). RAL was added at increasing molarities (1, 10 and $100 \mathrm{nM})$ to the SupT1 cell culture medium $24 \mathrm{~h}$ prior to HIV-1 infection, and maintained for 7 days [37]. No significant alteration of the cell viability was observed within this molarity range (Additional File 1). No viral integration was detectable at RAL molarities over $10 \mathrm{nM}$ (Table 3 and Additional File 1), a result which was consistent with the $\mathrm{IC}_{50}$ value of $10 \mathrm{nM}$ for RAL [37]. To further dissect the nature of the post-integration blockage of HIV-1 provoked by Ank ${ }^{\mathrm{GAG}} 1 \mathrm{D} 4$, the fate of the viral target of $A n k^{G A G} 1 D 4$, the Gag protein, was analyzed in HIV-1-infected SupT1 cells harvested at late times pi and subjected to cell fractionation. Whole cell lysates and cell fractions were assayed for Gag content by ELISA/CAp24, and the Gag protein pattern analysed by SDS-PAGE and Western blotting. The CAp24 levels were significantly lower in $\mathrm{Myr}+\mathrm{Ank}^{\mathrm{GAG}} 1 \mathrm{D} 4$ - and Myr0Ank ${ }^{\text {GAG }} 1$ D4-expressing cells, compared to control cells expressing no exogenous ankyrin or the Gag-irrelevant ankyrin Ank ${ }^{\mathrm{A} 3} 2 \mathrm{D} 3$ (Figure 12). A similar decrease was observed in the whole cell lysate and membrane fraction (Figure 12, compare panels A and B), implying that the antiviral effect of Ank ${ }^{G A G} 1 D 4$ did not involve the trafficking of Gag to the plasma membrane.

Western blot analysis showed a drastic reduction of all Gag protein species in $\mathrm{Myr}+\mathrm{Ank}^{\mathrm{GAG}} 1 \mathrm{D} 4$ - and Myr0-

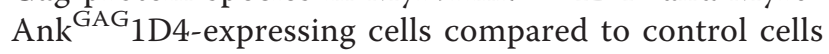




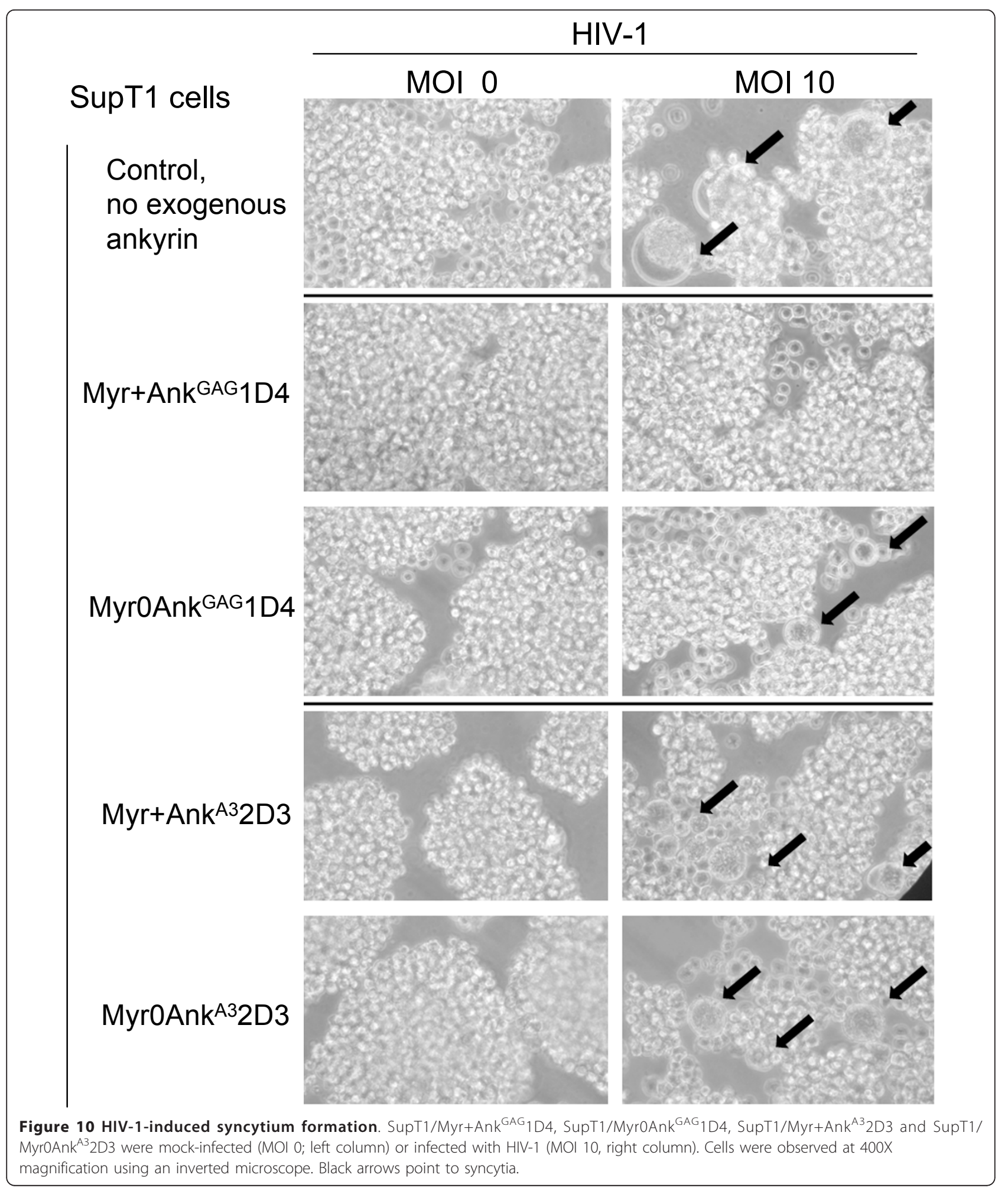

(Figure 12C, D). This pattern excluded a possible interference of $A n k{ }^{G A G} 1 D 4$ with the proteolytic processing of Gag, which might provoke a premature cleavage of the Pr55Gag precursor.
Viral specificity of Ank ${ }^{\mathrm{GAG}} 1 \mathrm{D} 4$

The viral specificity of Ank ${ }^{\mathrm{GAG}} 1 \mathrm{D} 4$ was evaluated on HIVLuc and Moloney murine leukemia virus (MLV)-Luc vectors, which express the luciferase-encoding reporter gene. 


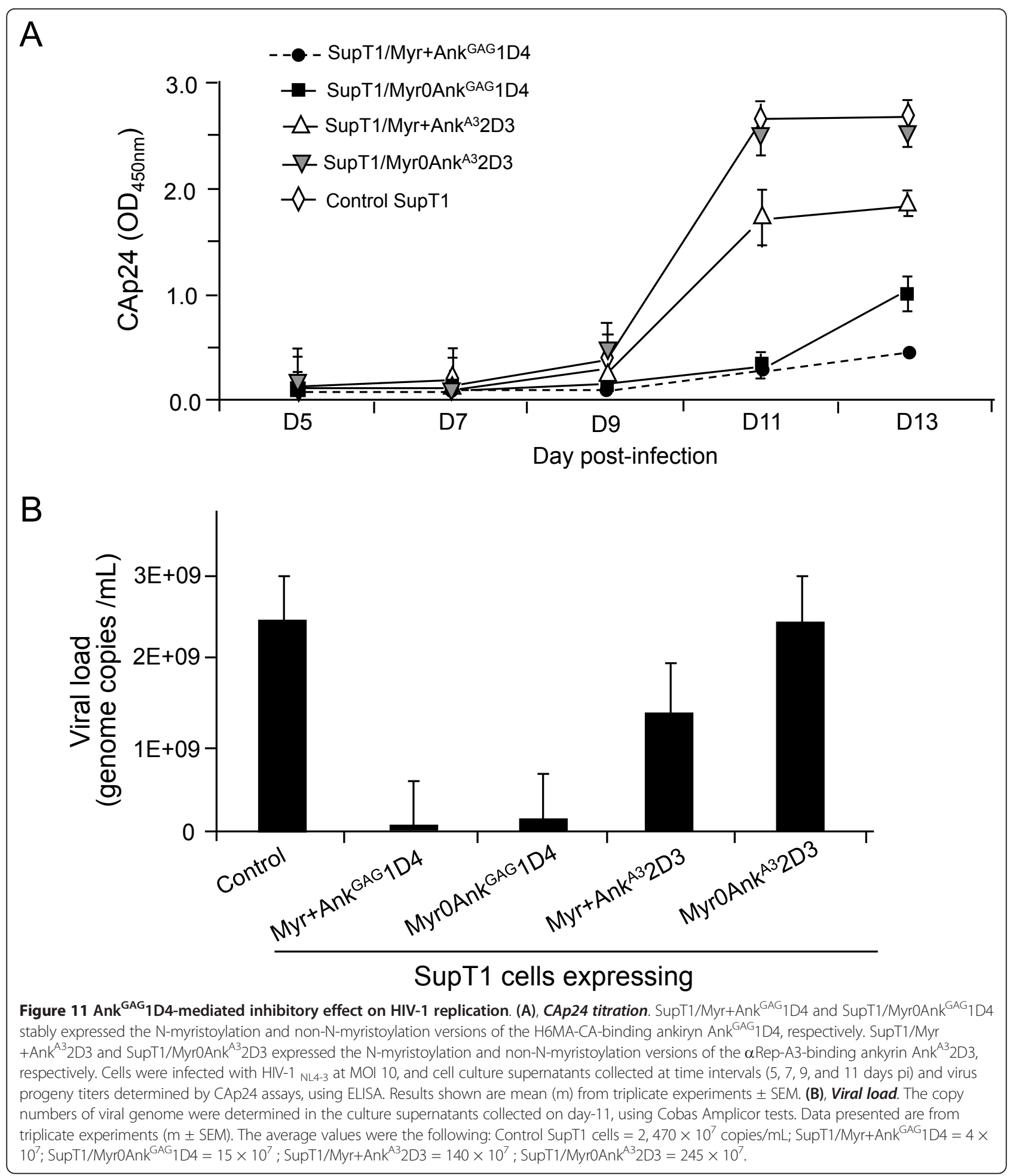

HIV-Luc was produced in 293T cells, and MLV-Luc was produced in the GP2-293-Luc packaging cells, which stably express the MLV gag-pol gene products and a packageable, luciferase-encoding MLV RNA transcript [38]. HIVLuc and MLV-Luc producer cells were transfected by the different pCEP4-ankyrin plasmids, and the extracellular media were collected at $72 \mathrm{~h}$ posttransfection and assayed for vector yields. Vector titers were determined by measuring the luciferase activity in HIV-Luc- and MLV-Luc-infected 293T cells [39]. The expression of 
Table 2 HIV-1 integration events in control and ankyrin-expressing SupT1 cells (a)

\begin{tabular}{ccccc}
\hline $\begin{array}{c}\text { Sequence } \\
\text { amplified }\end{array}$ & No ankyrin & Myr+Ank ${ }^{\mathrm{GAG}}$ 1D4 & Myr0Ank $^{\mathrm{GAG}} \mathbf{1 D 4}^{\mathrm{D}}$ & Myr+Ank $^{\mathbf{A 3}} \mathbf{2 D 3}$ \\
\hline Alu-gag junctions & $28.3 \pm 0.2$ & $28.6 \pm 0.3$ & $30.5 \pm 0.1$ & $27.8 \pm 0.2$ \\
GAPDH & $25.7 \pm 0.4$ & $26.1 \pm 0.5$ & $25.5 \pm 0.5$ & $24.5 \pm 0.1$ \\
\hline
\end{tabular}

(a) The level of HIV-1 integration in SupT1 cells harvested at day 11 pi was evaluated by quantitative PCR amplification of host cell DNA extracts, using primers specific to Alu-gag junctions, and to cellular GAPDH gene used as the internal control. Figures shown in the Table are Cts values, mean \pm SD ( $n=3$ ).

Myr+Ank ${ }^{\mathrm{GAG}} 1 \mathrm{D} 4$ and Myr0Ank ${ }^{\mathrm{GAG}} 1 \mathrm{D} 4$ in vector producer cells resulted in a 20-fold lower production of HIVLuc (Figure 13A), while MLV-Luc production was decreased by 6 - to 8 -fold (Figure 13B). These results suggested a significant degree of Ank ${ }^{\mathrm{GAG}} 1 \mathrm{D} 4$ cross-reactivity between HIV-1 and MLV, two evolutionarily divergent retroviruses. Of note, the expression of non-relevant ankyrins $\mathrm{Myr}+\mathrm{Ank}^{\mathrm{A} 3} 2 \mathrm{D} 3$ and $\mathrm{Myr} 0 \mathrm{Ank}^{\mathrm{A}}{ }^{\mathrm{A}} 2 \mathrm{D} 3$ decreased both HIV-Luc and MLV-Luc yields by a factor of 2, indicative of a basal interference level for ankyrins (Figure 13A, B).

\section{Discussion}

Although HAART can significantly reduce HIV-1 replication and prolong the life of HIV-infected individuals $[1,10]$, the treatment is lifelong, causes a variety of sideeffects with cumulative toxicities, and is responsible for the development of resistant viral strains [40]. Moreover, host genome-integrated proviral DNA persists in latent tissue reservoirs in HIV-1-infected individuals [1,10]. All these disadvantages have led many laboratories to consider the use of anti-HIV gene therapy, either as a standalone approach, or as an adjuvant to pharmacological regimens $[10,41]$. Gene therapy offers the potential of preventing progressive HIV infection by a sustained interference with the intracellular cascade that leads to virus replication. The aim of the present study was to investigate a novel class of intracellular protein-based antiviral agents, which would interact with viral proteins at critical steps of the virus life cycle and act as intracellular inhibitors of viral replication. One particular HIV-1

Table 3 HIV-1 integration events in control and Raltegravir-treated SupT1 cells ${ }^{\text {(a) }}$

\begin{tabular}{cllll}
\hline $\begin{array}{c}\text { Sequence } \\
\text { amplified }\end{array}$ & $\mathbf{0}$ & $\mathbf{1}$ & $\mathbf{1 0}$ & $\mathbf{1 0 0}$ \\
\hline Alu-gag junctions & $26.9 \pm 0.2$ & $36.1 \pm 0.3$ & $\mathrm{ND}$ & $\mathrm{ND}$ \\
\hline GAPDH & $23.3 \pm 0.5$ & $23.7 \pm 0.4$ & $24.1 \pm 0.3$ & $23.9 \pm 0.2$
\end{tabular}

(a) Aliquots of HIV-1-infected SupT1 cells were pretreated with Raltegravir at 0, 1,10 , and $100 \mathrm{nM}$, respectively, for $24 \mathrm{hr}$ prior to HIV-1 infection (MOI 10), and the drug maintained at the indicated concentrations for 7 days. Host cell genomic DNA was extracted on day 7 pi, and the level of HIV-1 integration in SupT1 cell lines was evaluated by quantitative PCR amplification of DNA extracts, using primers specific to Alu-gag junctions and to cellular GAPDH gene as the internal control. Figures shown in the Table are $C$ ts values (mean $\pm \mathrm{SD}, n=3$ ). ND, not detectable (below the threshold of detection). protein target which still lacks specific inhibitor(s) at the stage of clinical development is the Gag polyprotein precursor Pr55Gag and the late step of viral assembly [41-49]. The viral protein that we used as the target in this study was a truncated form of Gag precursor, consisting of the MAp17 and CAp24 domains (MA-CA), with ankyrin-derived repeat proteins acting as intracellular interactors and potential blockers.

Ankyrin-repeat proteins or DARPins represent potential candidates of anti-HIV-1 molecules, since they are considered as the best alternative to intracellular antibodies, single chain antibodies or intrabodies, in terms of binding affinity, specificity and stability $[12-14,23,26,27,30]$. The molecular architecture of ankyrin-derived repeat proteins consists of a common structural framework made of a theoretically unlimited number of helix-turn-helix repeat motifs or modules, arranged in a parallel orientation. The same positions in consecutive repeats can accommodate variable amino acid residues, selected randomly, with the exclusion of cysteine, glycine and proline [23]. All variable amino acid side chains are oriented on the same side of the helices (refer to Figure 3B), and are presented on a large solvent-accessible, hyper-variable surface which is well adapted to bind large surfaces on desired targets [22]. More importantly, the correct folding and stability of these molecules do not depend on disulfide bridge formation and can therefore occur in all environments, including extracellular and intracellular milieu, which is a major advantage over antibodies $[26,27,30]$. The number of modules is theoretically unlimited, and highly variable, in natural ankyrins, but the number of ankyrin modules in selected binders is generally restricted to two or three, although longer proteins up to fifteen modules are also present in libraries [23]. This is not due to a better functional adaptation of shorter ankyrins, but likely to the proportion of coding sequences in short versus longer proteins. Long ankyrin constructs are more likely to incorporate at least one frameshift mutation; thus the useful diversity of longer sequences is limited. Nevertheless, arrangements of two to three modules have enough surface and variability to generate binders with high affinity and specificity.

The construction of a DARPin library with random amino acids at predetermined, surface exposed positions in the conserved alpha-helical module of ankyrin required the use of oligonucleotides synthesized from 


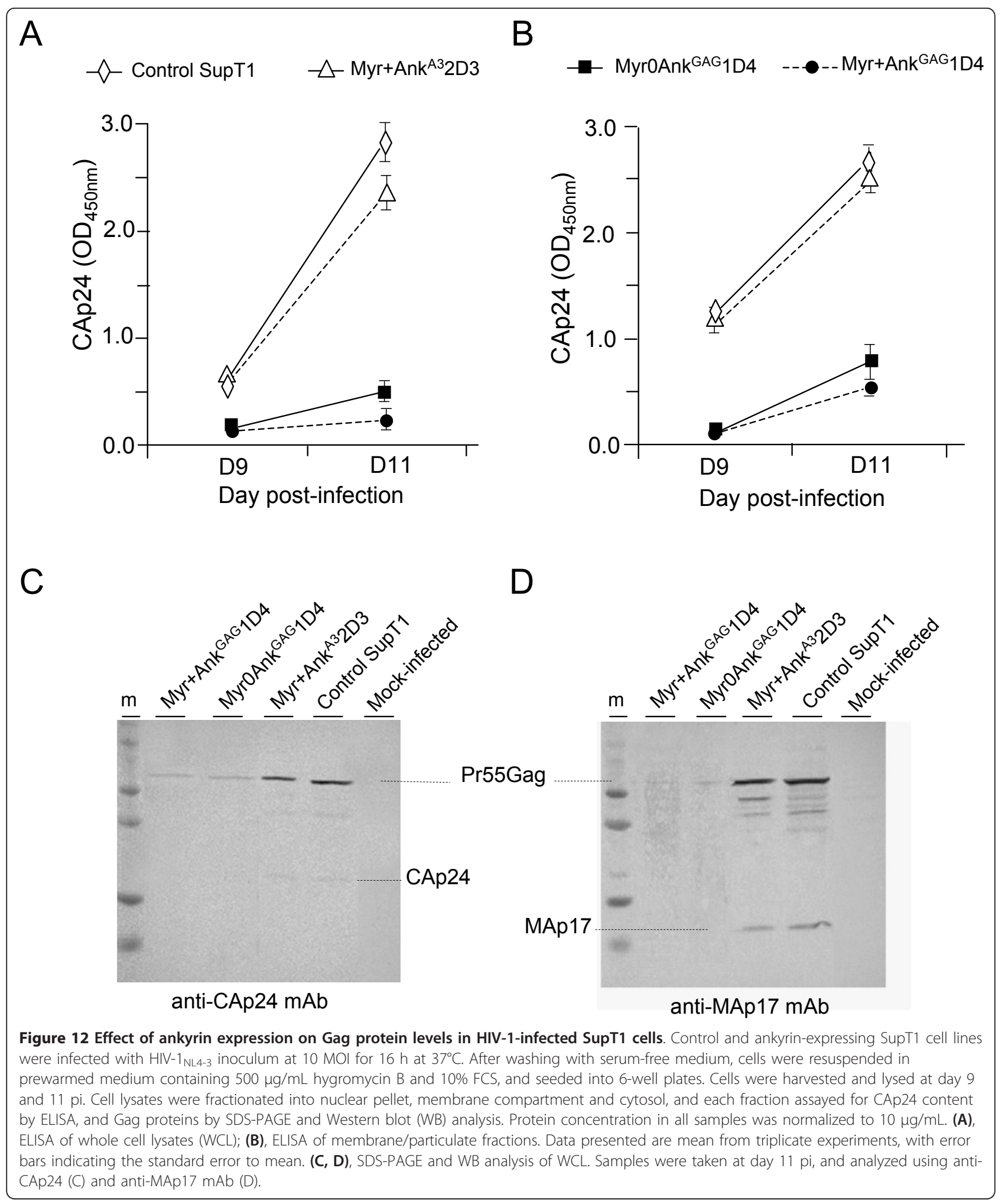

trinucleotide synthons. This constituted the major obstacle in the construction of such libraries, since this technology is not commonly accessible. To overcome this inconvenience, we developed an alternative strategy based on a mixture of partially degenerated oligonucleotides and generated a phage-displayed ankyrin-repeat library with a reasonable degree of diversity. What is referred to as 'useful diversity' of the ankyrin library 


\section{(A) HIV-LuC}

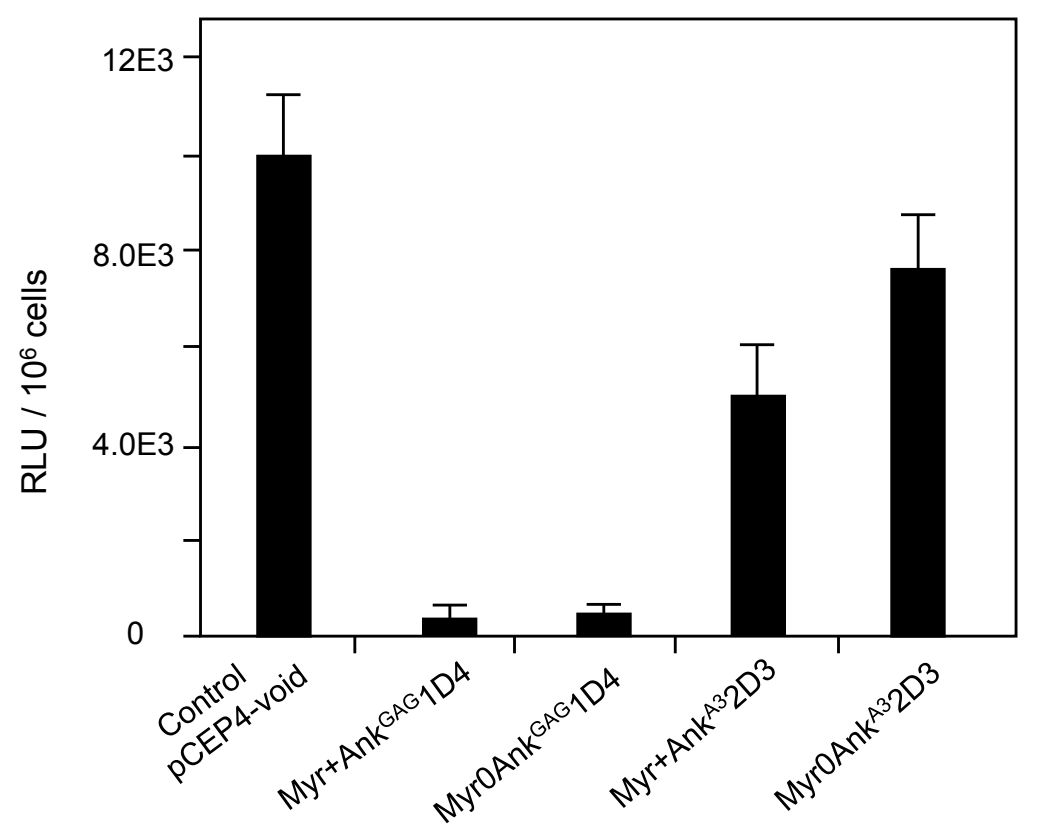

(B) MLV-LuC

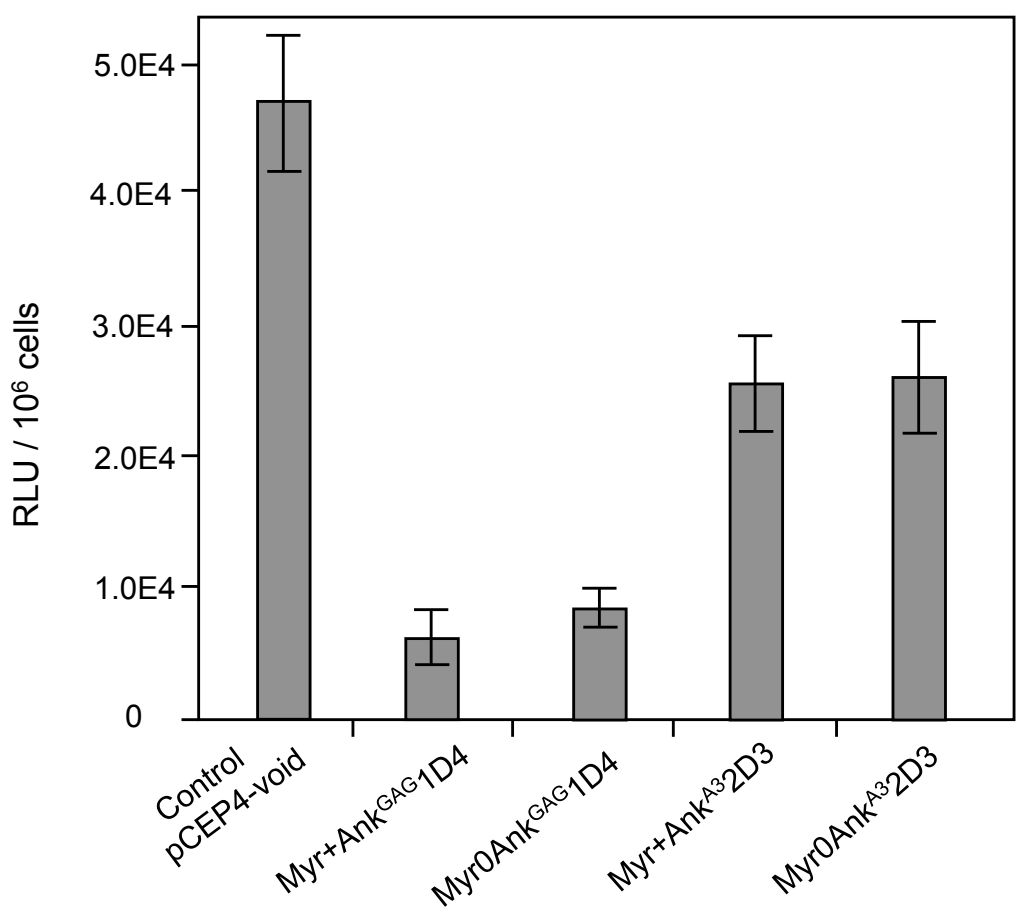

Figure 13 Influence of Ank ${ }^{\text {GAG }} 1$ D4 on the HIV-Luc (A) and MLV-Luc vector (B) yields. VSV-G-pseudotyped HIV-Luc released by $293 T$ cells cotransfected with pNL4-3Luc(R-E-), phCMV-G and pCEP4-ankyrin (A), and VSV-G-pseudotyped MLV-Luc vector released by GP2-293-Luc cells cotransfected with phCMV-G and PCEP4-ankyrin (B), were titrated on 293T cells, using the luciferase assay. RLU, relative light units. Data shown are $m \pm S E M, n=3$. 
generated in this study was estimated to be $6 \times 10^{7}$ independent coding sequences.

By screening our phage-displayed library on the MA-CA domains of HIV-1 Gag used as the bait, we isolated Ank ${ }^{\mathrm{GAG}} 1 \mathrm{D} 4$, a Gag-specific, trimodular ankyrin with an apparent molecular mass of $16.5 \mathrm{kDa}$. The potential capacity of Ank ${ }^{G A G} 1 D 4$ to interfere with HIV-1 replication was evaluated in SupT1 cells expressing the N-myristoylated (SupT1/Myr+Ank $\left.{ }^{\mathrm{GAG}} 1 \mathrm{D} 4\right)$ and the non-N-myristoylated (SupT1/Myr0Ank ${ }^{\mathrm{GAG}} 1 \mathrm{D} 4$ ) versions of $\mathrm{Ank}^{\mathrm{GAG}} 1 \mathrm{D} 4$, respectively. We observed a lower permissiveness to HIV1 for both cell lines, with a significant reduction of the HIV-1 progeny released in the culture medium, compared to control cells expressing Gag-irrelevant ankyrins or no exogenous ankyrin. The Ank ${ }^{\mathrm{GAG}} 1 \mathrm{D} 4$ anti-HIV-1 effect was found to occur at the post-integration phase of the virus life cycle, a result consistent with Gag, the viral structural protein being the target of $\mathrm{Ank}^{\mathrm{GAG}} 1 \mathrm{D} 4$. The results obtained with the MLV-Luc vector indicated that Ank ${ }^{\mathrm{GAG}} 1 \mathrm{D} 4$ could have antiviral effect on phylogenetically distant retroviruses. Interestingly, the interferon-induced cellular protein HERC5, which acts as a host restriction factor of HIV-1 infection, has been found to block both HIV-1 and MLV Gag particle assembly with a similar efficiency [50]. The cross-reactivity observed between HIV-1 and MLV implied that Ank ${ }^{\mathrm{GAG}} 1 \mathrm{D} 4$, which was selected on HIV-1 Gag, recognized a conformational structure or/ and motif conserved among retroviral Gag prolyproteins.

The mechanism of Ank ${ }^{\mathrm{GAG}} 1 \mathrm{D} 4$ activity was further dissected in HIV-1-infected SupT1 cells. No premature cleavage or sequestration of the Pr55Gag precursor in a cellular compartment was observed, but a lower Gag content was found in both Myr+Ank ${ }^{\mathrm{GAG}} 1 \mathrm{D} 4$ - and Myr0Ank ${ }^{\mathrm{GAG}} 1 \mathrm{D} 4$-expressing cells, compared to control cells. Image analysis of HIV-1-infected, ankyrin-expressing SupT1 cells suggested that the non-N-myristoylated Myr0Ank ${ }^{\mathrm{GAG}} 1 \mathrm{D} 4$ bound to nascent or newly synthesized Gag polyprotein within the cytoplasm, and that the Myr0Ank ${ }^{\text {GAG }}$ 1D4-Gag complex was addressed to the plasma membrane via the $\mathrm{N}$-myristoylation signal carried by Gag. $\mathrm{N}$-myristoylated $\mathrm{Myr}+\mathrm{Ank}^{\mathrm{GAG}} 1 \mathrm{D} 4$, however, was genetically designed for plasma membrane targeting. In both cases, the formation of Ank ${ }^{\mathrm{GAG}} 1 \mathrm{D} 4-\mathrm{Gag}$ protein complexes likely resulted in the depletion of Gag from the pool of molecules available for virus assembly. Although these results suggested that the specific interaction of Ank ${ }^{\mathrm{GAG}} 1 \mathrm{D} 4$ with the CA NTD negatively interfered with the Gag assembly and budding pathway at the plasma membrane, some interference with the interaction of Gag with the viral genomic RNA could not be excluded. This early interaction has been shown to occur at perinuclear/centromal sites [51] and could be the target of the cytoplasmic Myr0Ank ${ }^{\mathrm{GAG}} 1 \mathrm{D} 4$.
The molecular and cellular mechanism of the Ank ${ }^{\mathrm{GAG}} 1 \mathrm{D} 4$ antiviral effect might also involve the plasma membrane anchoring of Gag via its N-myristoylated signal. Several reports have shown a link between membrane anchoring of the Pr55Gag precursor and its translation. N-myristoylated Pr55Gag protein regulates its own translation in vitro in the presence of plasma membrane-containing fraction $[52,53]$. In the present study, SupT1/Myr+Ank ${ }^{\mathrm{GAG}} 1 \mathrm{D} 4$ cells showed a lower permissiveness to HIV-1 infection, compared to SupT1/ Myr0Ank ${ }^{\mathrm{GAG}} 1 \mathrm{D} 4$, suggesting that the addressing of Ank ${ }^{\mathrm{GAG}} 1 \mathrm{D} 4$ to the plasma membrane compartment via a N-myristoylated signal significantly increased its efficiency as antiviral agent. Furthermore, the plasma membrane-targeted, Gag-irrelevant ankyrin $\mathrm{Myr}+\mathrm{Ank}^{\mathrm{A} 3} 2 \mathrm{D} 3$ showed some negative interference with HIV-1 replication. It might be therefore hypothesized that $\mathrm{Myr}$ $+\mathrm{Ank}^{\mathrm{GAG}} 1 \mathrm{D} 4$ and $\mathrm{Myr}+\mathrm{Ank}^{\mathrm{A} 3} 2 \mathrm{D} 3$ occupied anchoring sites in critical domains of the plasma membrane inner leaflet which were required for the insertion of Pr55Gag/genomic RNA complex and the initiation of virus assembly [54-56]. Alternatively, but not exclusively, $\mathrm{Myr}+\mathrm{Ank}^{\mathrm{GAG}} 1 \mathrm{D} 4$ and $\mathrm{Myr}+\mathrm{Ank}^{\mathrm{A} 3} 2 \mathrm{D} 3$ might compete with Pr55Gag for $\mathrm{N}$-myristoyl-transferases, resulting in decreased levels of N-myristoylated Pr55Gag molecules competent for plasma membrane anchoring, and viral particle formation and egress. The latter hypothesis is consistent with a previous report describing the inhibitory effect of competing unsaturated fatty acids on viral budding [57].

The binding site of Ank ${ }^{\mathrm{GAG}} 1 \mathrm{D} 4$ was mapped to the $\mathrm{N}$-terminal moiety of the CA domain, within the first 110 residues. HIV-1 CA domain is composed of two highly structured subdomains, the $\mathrm{N}$-terminal subdomain (NTD, 1-145) and the C-terminal subdomain (CTD, residues 149-219), separated by a flexible hinge [58-60]. The Ank ${ }^{\mathrm{GAG}} 1 \mathrm{D} 4$ binding site encompassed two highly accessible and functionally important regions in the CA NTD: (i) the aminoterminal $ß$-hairpin, and (ii) the cyclophilinA (CypA) loop [58], which contains Proline-90 and Isoleucine-91. Pro-90 is the substrate of the CypA cis-trans peptidyl-prolyl isomerase, and Pro-90 and Ile-91 are two residues essential for virion incorporation of CypA, an HIV-1 infectivity factor [61-63]. Therefore, besides its effect on virus assembly, Ank ${ }^{\mathrm{GAG}} 1 \mathrm{D} 4$ could also decrease the infectivity of HIV-1 virions, via a blockage of the CypA encapsidation.

Retroviral Gag and GagPol polyproteins are incorporated into immature virus particles through Gag-Gag and Gag-GagPol interactions. In this assembly pathway, Gag dimerization, mediated by Gag-RNA interaction, represents a critical step [54-56,64-68]. Crystal analysis of HIV-1 CA has shown that the CTD is involved in the 
formation of CA dimers [58-60,69,70]. If the direct interaction of Ank ${ }^{\mathrm{GAG}} 1 \mathrm{D} 4$ with the CA NTD negatively interfered with the Gag multimerization process, this would occur via the NTD-NTD hexamerization interface, or the NTD-CTD interface, and not the CTD-CTD dimerization interface [58]. This differed from other peptide inhibitors of HIV-1 Gag assembly which have been shown to target the CTD-CTD interface and block the CA dimerization $[44,46,60]$. Analysis of the $\mathrm{H}_{6} \mathrm{MA}-\mathrm{CA} / \mathrm{Ank}^{\mathrm{GAG}} 1 \mathrm{D} 4 \mathrm{com}-$ plex suggested a stoichiometry of $1: 1$ for the pair of reagents, and a moderate affinity of Ank ${ }^{\mathrm{GAG}} 1 \mathrm{D} 4$ for its $\mathrm{H}_{6}$ MA-CA target in vitro. As a comparison, the dodecapeptide ITFEDLLDYYGP (abbreviated CAI, for capsid assembly inhibitor), isolated by screening of a phage-displayed peptide library on the HIV-1 CA domain, has been found to bind to CA with a $K_{\mathrm{d}}$ of $\sim 15 \mu \mathrm{M}$, and to inhibit the Gag multimerization and formation of immature virus particles at an average $50 \%$ inhibitory concentration of about $10 \mu \mathrm{M}[44,46]$.

\section{Conclusions}

The present study demonstrated the potential of ankyrin-repeat proteins as a novel class of intracellular antivirals. The data obtained with ankyrin Ank ${ }^{\mathrm{GAG}} 1 \mathrm{D} 4$ showed that a significant antiviral effect could be obtained with an ankyrin molecule targeted to a structural protein of the HIV-1 virion, which was the CA domain of the Gag precursor. The Ank ${ }^{G A G} 1 D 4$ molecule therefore represents an attractive platform for the design of more efficient ankyrin-based intracellular inhibitors of HIV-1 which would negatively interfere with the virus assembly and egress pathway. More generally, the antiviral activity shown by Ank ${ }^{\mathrm{GAG}} 1 \mathrm{D} 4$ should contribute to promote the use of ankyrin-repeat proteins as intracellular therapeutic agents against a variety of pathogens.

\section{Methods}

Cells

Human embryonic kidney cells HEK-293T cells were obtained from the American Type Culture Collection (ATCC, Manassas, VA), and maintained as monolayers in Dulbecco's modified Eagle's medium (DMEM; Invitrogen) supplemented with $10 \%$ fetal bovine serum (FBS; Invitrogen), penicillin $(100 \mathrm{U} / \mathrm{mL})$, and streptomycin $(100 \mathrm{mg} /$ $\mathrm{mL}$ ) at $37^{\circ} \mathrm{C}, 5 \% \mathrm{CO} 2 . \mathrm{GP} 2-293$ and GP2-293-Luc packaging cells stably expressed the Moloney murine leukemia virus (MLV) gag-pol gene products, and GP2-293-Luc contained an additional packageable, luciferase-encoding viral RNA transcript [38] expressed from the luciferase reporter vector pLLRN (BD Biosciences Clontech). Spodoptera frugiperda (Sf9) cells were maintained as monolayers at $28^{\circ} \mathrm{C}$ in Grace's insect medium supplemented with $10 \%$ fetal bovine serum (FBS) and antibiotics
(Invitrogen). They were infected with recombinant baculovirus at a multiplicity of infection (MOI) ranging from 2 to $10 \mathrm{PFU} /$ cell, as previously described [71-74]. SupT1 cell lines stably expressing the ankyrin-repeat proteins were generated using the pCEP4-based vector (Invitrogen). Transfected SupT1 cells were maintained in complete RPMI containing hygromycin B $(400 \mu \mathrm{g} / \mathrm{mL})$.

\section{Plasmids and vectors}

Plasmid pQE-30 (Qiagen) was used for production of 6xHis-tagged recombinant proteins in bacterial cells. Plasmid pNL4-3, obtained from the NIH AIDS Research and Reference Reagent Program (Division of AIDS, NIAID, NIH), was used as the template for isolation of the DNA fragments encoding the wild-type HIV-1 MA$\mathrm{CA}$ and CA domains, and insertion into the pBlueBac4.5 plasmid (Invitrogen). The pBlueBac4.5 transfer vector was recombined with the genome of Autographa californica multiple nucleopolyhedrosis virus (AcMNPV), to generate recombinant baculoviruses AcMNPV- ${ }_{6} \mathrm{MA}-$ $\mathrm{CA}$ and AcMNPV- $\mathrm{H}_{6} \mathrm{CA}$ were used to produce the $\mathrm{H}_{6} \mathrm{MA}-\mathrm{CA}$ and $\mathrm{H}_{6} \mathrm{CA}$ recombinant proteins. The pCEP4 vector (Invitrogen) was used for constitutive, episomal expression of designed ankyrins from the CMV promoter in SupT1 cells. VSV-G-pseudotyped HIV-1-luciferase vector was recovered from the culture supernatant of 293T cells cotransfected with equal doses of pCEP4ankyrin, phCMV-G and pNL4-3Luc(R-E-) plasmids (3 $\mu \mathrm{g}$ of each plasmid per $10^{6}$ cell aliquots), as previously described [39]. VSV-G-pseudotyped MLV-luciferase vector was recovered from the culture supernatant of GP2293-Luc cells cotransfected with equal doses $\left(3 \mu \mathrm{g} / 10^{6}\right.$ cells) of pCEP4-ankyrin and phCMV-G. Cell culture supernatants containing the VSV-G-pseudotyped HIV-1 or MLV vectors (abbreviated HIV-Luc and MLV-Luc, respectively) were harvested at $72 \mathrm{~h}$ posttransfection, aliquoted and used for infection of $293 \mathrm{~T}$ cells. HIV-Luc or MLV-Luc vector titers were determined at $24 \mathrm{~h}$ pi by luciferase assay of $293 \mathrm{~T}$ cell lysates [39].

\section{Construction of ankyrin-repeat protein library}

The artificial ankyrin library was constructed using a combined phage display/expression vector based on pHDiExDsbA-Ank15 [75]. This vector was used for low level expression of DARPins fused to the M13 g3p truncated protein in phage display experiments. Since this construction had also a T7 promoter and a suppressible stop codon between the DARPins and g3p coding sequences, it could also be used for periplasmic expression of nonfused DARPins in non supE strains of E. coli expressing T7 polymerase. DARPins are extremely stable proteins and are efficiently translocated to periplasmic space only provided that they are fused to the SRP export sequence [76]. For cytoplasmic expression, the sequence 
encoding soluble ankyrin proteins were inserted into the pQE-30 expression vector (Qiagen), using M15 (pREP4) strain (Qiagen) for expression. Bacterial cells XL-1 Blue MRF' (Stratagene) were used as host cells for the generation of the library and propagation of phages displaying the artificial ankyrin-repeat protein library.

The generation of our artificial ankyrin-repeat proteins library was based on that of DARPins library previously described [23], with the following modifications. A limited number of changes were introduced in the ankyrinrepeat consensus sequence in order to create a type II non-palyndromic restriction site Bsm BI within the ankyrin module. This site was used to produce ankyrin module-encoding microgenes from circularly amplified products and for their subsequent directional polymerization, in order to create the library. The Bsm BI recognition site was introduced by replacing glutamate- 21 by arginine (E21R substitution) and valine-22 by leucine (V22L), using the appropriate nucleotide changes. In order to minimize possible charge repulsion involving the newly introduced R21, a compensatory change was made, consisting of a K-to-E mutation at position 25, which introduced a negative charge in the consecutive turn of the same alpha helix. These modifications were not expected to interfere with the folding or stability of the ankyrin module, since these types of amino acid residues are commonly found at equivalent positions of natural protein with ankyrin repeats. Furthermore, the changes that we created were located on the face of the protein opposite to the binding surface, and therefore should not interfere with the potential binding activity of the artificial ankyrins.

Further changes with respect to previously described libraries were introduced in the design of this library. The side chain of residue located at position 10 (helix-1) was oriented toward the binding surface and was therefore partially randomized, while position 26 and 33, not directly located within the binding surface, were kept constant. In DARPins libraries previously described, the modification of each variable amino acids of the ankyrin repeats were essentially performed randomly, with the exclusion of cysteine $(C)$, glycine $(\mathrm{G})$ and proline $(\mathrm{P})$. This was made possible by using oligonucleotides synthesized from trinucleotide synthons. As this technology is not commonly accessible, we devised an alternative strategy based on a mixture of partially degenerated oligonucleotides, and comprising of the following steps (Figure 2).

(i) The oligonucleotides pools were designed to exclude undesired cysteine residues and to mimic the natural residue frequency of residues at each defined position where amino acid residues could vary, i.e. position numbers 2,3 , 5, 10, 13 and 14 (Table 1). The position-specific, natural distribution of amino-acids frequencies were computed from the natural ankyrin modules collections defined in the Prosite database (PS50088). The choice for the set of partially degenerated codons was in fact a compromise, in order to minimize the numbers of codons (and therefore of oligonucleotides), while maintaining the side chains diversity close to the chemical diversity encountered in natural ankyrin-repeat proteins.

(ii) The repeat sequences were generated by using a set of oligonucleotides containing a set of partially degenerated codons. The sequence coding a single repeat was divided into four fragments (Figure 1): Va (variable fragment a), $\mathrm{Vb}$ (variable fragment b), $\mathrm{Vc}$ (variable fragment $\mathrm{c}$ ) and $\mathrm{C} 1$ (constant fragment). Each variable fragment was generated by mixing a pool of oligonucleotides with randomized positions encoded with different combination of partially degenerated codons (Table 1 ).

(iii) All synthetic fragments $(\mathrm{Va}, \mathrm{Vb}, \mathrm{Vc}$, and $\mathrm{C} 1)$ were hybridized with reverse oligonucleotides linkers ("bridging" fragments; Vb-rev, C2, and C3) at equal molarity by heating at $95^{\circ} \mathrm{C}$ for $5 \mathrm{~min}$, followed by progressive refrigeration to $25^{\circ} \mathrm{C}$ at the rate of $0.1^{\circ} \mathrm{C} / \mathrm{min}$.

(iv) To generate the circularized template, the hybridized product was ligated by T4 DNA ligase (New England Biolabs, NEB), purified using the NucleoSpin ${ }^{\mathbb{B}}$ Extract II kit (Macherey-Nagel), and used as the template for Rolling Circle Amplification (RCA) process, using the Illustra TempliPhi 100 amplification kit (GE Healthcare, Bio-Sciences).

(v) The polymerized product was incubated at $65^{\circ} \mathrm{C}$ for $15 \mathrm{~min}$ and subsequently treated with $\mathrm{BsmB}$ I (NEB) at $55^{\circ} \mathrm{C}$ for $4 \mathrm{~h}$, resulting in a mixture of mono-repeat ankyrin microgenes.

(vi) The mixture of generated fragments was subjected to a hetero-polymerization process for the generation of repeat protein library, using a procedures adapted from a previous work on a different type of repeat protein [33]. In brief, the pool of mono-repeat ankyrin microgenes were inserted into and ligated to a specially designed "acceptor" vector containing the $\mathrm{N}$ - and C-cap of DARPins (Figure 2). This vector was first cleaved with BsmB I and Kpn I (Fermentas) to generate the cohesive ends compatible with ankyrin repeats microgenes. The Kpn I cleavage, although not strictly necessary, was used to minimize the vector recircularization which would compete with ankyrin-repeat polymerisation. Once ankyrin repeats were ligated with N-Cap, vector was cleaved with BspM I (NEB) and recircularised by intramolecular ligation. This resulted in the elimination of the Rep cloning sites regions and its replacement by a variable number of ankyrin repeats between the $\mathrm{N}$ - and $\mathrm{C}$-caps. The ligation product was transfected into electrocompetent XL-1 Blue cells. Transformed cells were selected on LB agar containing ampicillin $(100 \mu \mathrm{g} / \mathrm{mL})$. The number of ankyrin repeats was determined by gel electrophoresis, after digestion of 
the vector pool with Not I (NEB) and Hind III (NEB). The quality of the ankyrin library, based on the proportion of readthrough clones, was evaluated by $\mathrm{CoFi}$ blot analysis as previously described [33].

\section{Construction of expression vectors}

(i) Baculoviral vectors (AcMNPV). The baculovirus transfer vector encoding His-tagged MA-CA domains of Gag $\left(\mathrm{H}_{6} \mathrm{MA}-\mathrm{CA}\right)$ was generated as described elsewhere [77]. For production of recombinant His-tagged CAp24 domain of $\mathrm{Gag}\left(\mathrm{H}_{6} \mathrm{CA}\right)$, the gene encoding $\mathrm{H}_{6} \mathrm{CA}$ was amplified from the parental vector pNL4-3 by standard PCR protocol using pair of primers: FWD-p24 Nhe I, 5'GAGGAGGAGGTGCTATAGTGCAGAACCTCCAG-3' and REV-p24 Kpn I, 5'-GAGGAGGAGCTGGTACCTTACAAAACTCTTGCTTTATGGCC-3'. The PCR fragment was treated with Nhe I and Kpn I and subsequently cloned into the pBlueBac4.5 transfer vector, resulting in plasmid pBlueBac- $\mathrm{H}_{6} \mathrm{CA}$.

(ii) Bacterial cell vectors ( $p Q E-30)$. Ankyrin genes encoding $\mathrm{H}_{6}$ MA-CA or $\alpha$ Rep-A3-binder ( $\alpha$ Rep-previously described as $\alpha$ Rep-n4-a (pdb-code 3LTJ; [33]) were inserted into the $\mathrm{pQE}-30$ ankyrin acceptor vector, designed for soluble protein production. The acceptor vector was constructed by inserting the hybridization product of two synthetic oligonucleotides, pQE-Ank-Adapt-Fw (5'GATCCGCGGCCGCAAACGCGTAAA-3') and PQEAnk-Adapt-Re (5'-AGCTTTTACGCGTTTGCGGCCG CG-3'), into the Bam HI and Hind III sites of the pQE-30 vector, resulting in the insertion of a Not I restriction site into $\mathrm{pQE}-30$. Phagemid $\mathrm{pHDiExDsbA}$ was treated with Not I and Hind III, and the resulting Not I-Hind III fragment was cloned into the same sites of the pQE-30 acceptor vector. The resulting $\mathrm{PQE}-30$ vector contained the gene coding for Gag-binding or $\alpha$ Rep-A3-binding ankyrin. All vector constructs were transfected into E.coli M15 [pREP4] (Qiagen).

(iii) Mammalian cell vectors ( $p$ CEP4). Two versions of ankyrin-coding vectors, pCEP4-Myr ${ }^{+}$Ank-GFP and pCEP4-Myr0Ank-GFP, were constructed. The N-myristoylated ankyrin-GFP fusion protein expressed by pCEP4$\mathrm{Myr}^{+} \mathrm{Ank}^{\mathrm{GAG}} 1 \mathrm{D} 4-\mathrm{GFP}$ was designed to be directed to the plasma membrane, whereas the non- $\mathrm{N}$-myristoylated ankyrin-GFP fusion protein expressed by pCEP4-Myr0Ank ${ }^{\mathrm{GAG}} 1 \mathrm{D} 4-\mathrm{GFP}$ was designed to localize in the cytoplasm. The DNA encoding the Gag-binders Ank ${ }^{\mathrm{GAG}} 1 \mathrm{D} 4$ and control $\mathrm{Ank}^{\mathrm{A} 3} 2 \mathrm{D} 3$ were amplified from their respective pHDiExDsbA-encoding plasmids using two sets of primer with or without the N-myristoylation signal at the 5 'end. The gene encoding the green fluorescent protein (GFP) was amplified from pTriEx-GFP [78], using primers of which sequence will be communicated upon request. PCR products encoding Ank ${ }^{\mathrm{GAG}} 1 \mathrm{D} 4$ or $\mathrm{Ank}^{\mathrm{A} 3} 2 \mathrm{D} 3$ fused to GFP were recombined by overlapping PCR. The PCR products of the second round were treated with $K p n$ I and Xho I (Fermentas) and cloned into corresponding sites of the pCEP4 vector. The sequence of Ank ${ }^{\mathrm{GAG}} 1 \mathrm{D} 4-\mathrm{GFP}$ and $\mathrm{Ank}^{\mathrm{A} 3}$ 2D3-GFP, as well as all our other constructs, was verified by standard DNA sequencing.

\section{Production of recombinant $\mathrm{H}_{6} \mathrm{MA}-\mathrm{CA}$ and $\mathrm{H}_{6} \mathrm{CA}$ proteins in baculovirus-infected cells}

Sf9 cells were cotransfected with $10 \mu \mathrm{g}$ each of pBlueBac4.5- $\mathrm{H}_{6}$ MA-CA (or pBlueBac4.5- $\mathrm{H}_{6} \mathrm{CA}$ ) and Bac-NBlue $^{\mathrm{TM}}$ DNA, using Cellfectin ${ }^{\circledR}$ II reagent, using the conditions recommended by the manufacturer (Invitrogen). The recombinant viruses obtained, BV- $\mathrm{H}_{6} \mathrm{MA}-\mathrm{CA}$ and $\mathrm{BV}-\mathrm{H}_{6} \mathrm{CA}$, were isolated using the blue plaque selection method, and amplified. BV- $\mathrm{H}_{6} \mathrm{MA}-\mathrm{CA}$ - and BV- $\mathrm{H}_{6} \mathrm{CA}$-infected $\mathrm{Sf} 9$ cells were harvested at $48 \mathrm{~h}$ postinfection (pi), lysed by freezing and thawing. The cell lysates were clarified by centrifugation at $15,000 \times$ $\mathrm{g}$ for $30 \mathrm{~min}$ at $4^{\circ} \mathrm{C}$. The presence of recombinant Gag proteins was detected by SDS-PAGE and Western blotting. The nitrocellulose membranes (GE Healthcare BioSciences) were incubated with blocking solution (5\% skimmed milk in TBS) for $1 \mathrm{~h}$ at RT, and Gag proteins detected using monoclonal anti-His-tag antibody (1:5, 000 dilution in the blocking solution) for $1 \mathrm{~h}$ at $\mathrm{RT}$ with slow rocking. After washing with TBST (TBS containing $0.05 \%$ Tween 20 ), membranes were incubated with HRP-conjugated goat anti-mouse Ig (1:8, 000 dilution in blocking solution) for $1 \mathrm{~h}$ at RT. After two extra washing steps, the Gag proteins were visualized using TMB membrane peroxidase substrate (KPL). His-tagged Gag proteins were purified from clarified Sf9 cell lysates by affinity chromatography on HisTrap column, using ÄKTA prime ${ }^{\mathrm{TM}}$ plus (GE Healthcare Bio-Sciences). Protein concentration was determined using the Bradford protein assay (Thermo Fisher Scientific Inc.). Purity of His-tagged Gag proteins was assessed by SDS-PAGE analysis in $15 \%$ acrylamide gel and Coomassie blue staining [77].

\section{Phage selection}

Microtiter plate (NUNC) was coated with $100 \mu \mathrm{H}_{6} \mathrm{MA}$ CA protein (or $\alpha$ Rep-A3 protein) solution at $20 \mu \mathrm{g} / \mathrm{mL}$ in sterile PBS, overnight at $4^{\circ} \mathrm{C}$. Purified $\alpha$ Rep-A3 protein, produced as described [33], was used as a control for evaluating the quality of our artificial ankyrin library against a properly folded protein target. Plates were washed four times with sterile-filtered TBST. Non-specific binding was prevented by blocking with sterile-filtered blocking buffer (2\% BSA in TBST; $200 \mu$ l per well) for $1 \mathrm{~h}$ at RT with shaking at $150 \mathrm{rpm}$ on an Eppendorf Thermomixer $^{\circledR}$ (Eppendorf). After a washing step with TBST, $100 \mu \mathrm{l}$ of phage suspension, corresponding to $10^{11}$ particles, was added per well. After $1 \mathrm{~h}$ incubation 
at RT with shaking, plates were washed 20 times with TBST and 10 times with TBS. Substrate-bound phages were eluted by postincubation with $100 \mu \mathrm{l}$ of $0.1 \mathrm{M}$ glycine solution at $\mathrm{pH} 2.5$, for $10 \mathrm{~min}$ at $\mathrm{RT}$ with shaking, followed with $\mathrm{pH}$ neutralization using $12.5 \mu \mathrm{l} 1 \mathrm{M}$ Tris$\mathrm{HCl}$ buffer, $\mathrm{pH}$ 8. The eluted phages were mixed with $5 \mathrm{ml}$ of XL-1 Blue cell suspension $\left(\mathrm{OD}_{600}\right.$ 0.6-0.8), and the mixture incubated for $30 \mathrm{~min}$ at $37^{\circ} \mathrm{C}$. Bacterial cells were centrifuged at $1,200 \times g$ for $10 \mathrm{~min}$ at $25^{\circ} \mathrm{C}$, pellet resuspended in $1 \mathrm{ml} 2 \mathrm{X}$ YT broth and plated on $\mathrm{LB}$ agar containing ampicillin $(100 \mu \mathrm{g} / \mathrm{mL})$. Bacterial colonies were pooled, and used for phage preparation to perform the next round of phage selection. Individually picked, single colonies of the second and third rounds of selection were screened by phage ELISA.

\section{Expression and purification of soluble ankyrins with Gag- binding activity}

M15[pREP4] bacterial cells harboring the pQE30-ankyrin plasmid were grown in $500 \mathrm{ml}$ LB broth supplemented with ampicillin $(100 \mu \mathrm{g} / \mathrm{mL})$, kanamycin $(25 \mu \mathrm{g} / \mathrm{mL})$, and $1 \%(w / v)$ glucose, at $37^{\circ} \mathrm{C}$ with shaking until $\mathrm{OD}_{600}$ reached 0.8 . Protein expression was induced by addition of $1 \mathrm{mM}$ IPTG, and maintained in culture for $4 \mathrm{hr}$ at $30^{\circ} \mathrm{C}$ with shaking. Bacteria were pelleted by centrifugation at 1 , $200 \times g$ for $30 \mathrm{~min}$ at $4^{\circ} \mathrm{C}$. Pellets were resuspended in lysis buffer and subjected to three cycles of freezing and thawing. Lysis buffer consisted of TBS buffer, $\mathrm{pH}$ 7.4, containing $1 \mu \mathrm{g} / \mathrm{mL}$ lysozyme and a cocktail of protease inhibitors (Roche Diagnostics $\mathrm{GmbH}$ ). Bacterial cell lysates were clarified by centrifugation at $15,000 \times g$ for $30 \mathrm{~min}$ at $4^{\circ} \mathrm{C}$. The soluble form of Gag-interacting ankyrins was purified from the clarified bacterial lysates by a two-step procedure comprising of affinity chromatography on HisTrap column followed by gel filtration on Sephadex G-75 (GE Healthcare Bio-Sciences). Proteins were analyzed by SDS-PAGE and Coomassie blue staining, or SDSPAGE and Western blotting, as detailed below.

\section{Biotinylation of soluble ankyrins}

Purified Gag-binding ankyrins were chemically biotinylated using the EZ-Link Sulfo-NHS-LC-Biotin kit (ThermoScientific, Rockford, IL). In brief, a solution of purified protein at $100 \mu \mathrm{M}$ was mixed with a 5 -fold molar excess of Sulfo-NHS-Biotin solution in a final volume of $2 \mathrm{ml}$, and incubated at $25^{\circ} \mathrm{C}$ for $1 \mathrm{~h}$. Excess reagents and by-products were removed by applying the mixture to a pre-equilibrated Zeba ${ }^{\mathrm{TM}}$ Desalt Spin column (ThermoScientific). The column was centrifuged at $1,000 \times \mathrm{g}$ for $2 \mathrm{~min}$, and the biotinylated proteins were recovered in the flow-through fraction. The concentration of biotinylated proteins was determined using the NanoDrop 2000 system (ThermoScientific). The biotinylation efficiency of proteins was qualitatively evaluated using dot-blot analysis. $10 \mu \mathrm{mol}$ biotinylated proteins was spotted on nitrocellulose membrane, membrane blocked with blocking buffer (5\% BSA in TBS), and biotin groups revealed by extravidin-HRP (Sigma) used at dilution 1:5, 000 in blocking buffer ( $1 \mathrm{~h}$ at RT with shaking) and BM Blue POD Substrate (Roche Diagnostics $\mathrm{GmbH}$ ).

\section{Assessment of ankyrin reactivity towards HIV-1 MA-CA polyprotein}

(i) Competitive ELISA. Microtiter plates were coated with $100 \mu \mathrm{l}$ of purified $\mathrm{H}_{6}$ MA-CA or $\alpha$ Rep-A3 $(1 \mu \mathrm{g} / \mathrm{mL})$ diluted in PBS and left overnight at $4^{\circ} \mathrm{C}$ in a moisture chamber. The coated wells were washed four times with TBST and incubated with $200 \mu \mathrm{l}$ blocking solution (2\% BSA in TBS) for $1 \mathrm{~h}$ at RT. After washing, $100 \mu \mathrm{l}$ biotinylated Gag-binding ankyrin at $10 \mu \mathrm{M}$, alone or mixed with an equal molar amount of competitor (non-biotinylated ankyrin or irrelevant ankyrin), was added and incubated for $1 \mathrm{~h}$ at RT. Plates were then washed and incubated with extravidin-HRP diluted to 1:5, 000 in blocking solution for $1 \mathrm{~h}$ at RT. After washing, $100 \mu \mathrm{l}$ of TMB substrate was added, and the reaction was blocked by addition of $1 \mathrm{~N}$ $\mathrm{HCl}$. OD was measured at $450 \mathrm{~nm}$ using a MTP-120 ELISA plate reader (Corona Electric, Ibaraki, Japan).

(ii) Far Western blotting. Lysates of Sf9 cells infected by BV- $\mathrm{H}_{6}$ MA-CA were analyzed by SDS-PAGE and proteins transferred to polyvinylidene fluoride (PVDF) membrane (GE Healthcare Bio-Sciences). Membranes were incubated in blocking buffer (5\% BSA in TBS) overnight at $4^{\circ} \mathrm{C}$, then postincubated with biotinylated Gag-binding ankyrins at $1 \mu \mathrm{M}$ for $1 \mathrm{~h}$ at RT with gentle rocking. Substrate-bound biotinylated-ankyrins were detected by reaction with extravidin-HRP (diluted to 1:10, 000 in blocking buffer) and $\mathrm{TMB}$ membrane peroxidase substrate (KPL).

\section{Mapping of ankyrin binding site on HIV-1 Gag precursor}

(i) Specificity assay. The specificity of the Gag-binding ankyrins towards the CA domain was performed by indirect ELISA. Lysates of BV- $\mathrm{H}_{6} \mathrm{CA}$-infected cells were added to nickel pre-coated wells, as described elsewhere [79]. Biotinylated Gag-binding ankyrins were individually reacted with immobilized $\mathrm{H}_{6} \mathrm{CA}$ domain for $1 \mathrm{~h}$ at $37^{\circ} \mathrm{C}$. The binding reaction was monitored by adding extravidinHRP (dilution 1:5, 000) and TMB substrate. After stopping reaction with $1 \mathrm{~N} \mathrm{HCl}$, the signals were measured at $\mathrm{OD}_{450}$, as above described.

(ii) Mapping. The ankyrin binding site on the CA domain was determined using Gag amber mutants $(\mathrm{Gag} a \mathrm{mb})$ expressed as recombinant proteins in baculovirus-infected cells [36]. Lysates of Sf9 cells expressing Gagamb276 or Gagamb241 polyprotein were coated on ELISA plates and reacted with biotinylated Gag-binding ankyrins, as above. 


\section{Microcalorimetry analysis of Gag-ankyrin binding parameters}

Interaction between proteins was analyzed by isothermal titration calorimetry (ITC), using the MicroCal iTC 200 isothermal titration microcalorimeter (Microcal), under the conditions described in a previous study [80]. All proteins were diluted in $20 \mathrm{mM}$ phosphate buffer pH7.5, $150 \mathrm{mM}$ $\mathrm{NaCl}$. For each injection, $2 \mu \mathrm{l}$ of ankyrin solution was added from a computer-controlled $40-\mu \mathrm{l}$ microsyringe at intervals of $180 \mathrm{~s}$ into the protein substrate solution, $\mathrm{H}_{6}$ MA-CA or $\alpha$ Rep-A3. A theoretical titration curve was fitted to the experimental data, as previously described [80].

\section{Construction of cell lines stably expressing ankyrins}

Aliquots of SupT1 cells $\left(10^{6}\right.$ cells) were electroporated with pCEP4-based vectors encoding GFP-fused ankyrins with $(\mathrm{Myr}+)$ or without (Myr0) the myristoylation signal, using the Nucleofector ${ }^{\mathrm{TM}}$ (Lonza, Basel, Switzerland) and the Nucleofector ${ }^{\mathrm{TM}}$ transfection reagent $\mathrm{V}$ (Lonza), according to protocol T-16. Transfected cells were maintained in complete RPMI containing hygromycin B (400 $\mu \mathrm{g} / \mathrm{mL})$. Four cell lines were generated, SupT1/Myr +Ank ${ }^{\mathrm{GAG}} 1 \mathrm{D} 4$-GFP, SupT1/Myr0Ank ${ }^{\mathrm{GAG}} 1 \mathrm{D} 4$-GFP, SupT1/Myr+Ank ${ }^{\mathrm{A} 3}$ 2D3-GFP and SupT1/MyrOAnk ${ }^{\mathrm{A} 3}$ 2D3GFP, respectively. The level of expression of Ank ${ }^{\mathrm{GAG}} 1 \mathrm{D} 4-$ GFP and control Ank ${ }^{\mathrm{A} 3}$ 2D3-GFP proteins was monitored by flow cytometry of the GFP signal, and cellular localization by confocal fluorescence microscopy. For flow cytometry, cells were blocked by incubation with human $A B$ serum on ice for $30 \mathrm{~min}$. They were reacted with $50 \mu \mathrm{l}$ of purified anti-CD4 mAb MT4-3 [81] at $20 \mu \mathrm{g} / \mathrm{mL}$ in $1 \%$ $\mathrm{BSA}-\mathrm{PBS}-\mathrm{NaN}_{3}$ on ice for $30 \mathrm{~min}$. At the end of the incubation time, the cells were washed three times with PBS, and incubated with $25 \mu \mathrm{l}$ PE-conjugated rabbit anti-mouse $\mathrm{F}(\mathrm{ab}) 2$ (DAKO) on ice for $30 \mathrm{~min}$. Cells were washed, fixed in $1 \%$ paraformaldehyde in PBS, and analyzed by flow cytometry.

\section{HIV-1 challenge}

To evaluate the effect of Gag-binding ankyrins on the HIV-1 life cycle, SupT1 cells stably expressing the Myr ${ }^{+}$ or Myr0 version of the best Gag binder Ank ${ }^{\mathrm{GAG}} 1 \mathrm{D} 4$ and irrelevant control Ank ${ }^{\mathrm{A} 3} 2 \mathrm{D} 3$, were challenged with HIV1 virions (NL4-3 strain). Triplicate samples of SupT1/ Myr+Ank ${ }^{\mathrm{GAG}} 1 \mathrm{D} 4$, SupT1/Myr0Ank ${ }^{\mathrm{GAG}} 1 \mathrm{D} 4$, SupT1/Myr + Ank $^{\mathrm{A} 3} 2 \mathrm{D} 3$ and SupT1/Myr0Ank ${ }^{\mathrm{A} 3} 2 \mathrm{D} 3$ were infected at MOI 10 for $16 \mathrm{~h}$ at $37^{\circ} \mathrm{C}$. The virus infectivity titer was determined from the genome copy number measured by quantitative RT-PCR (Roche Diagnostics). Cells were then washed three times with serum-free medium, resuspended in $3 \mathrm{~mL}$ of fresh medium containing $400 \mu \mathrm{g} / \mathrm{mL}$ hygromycin B and 10\% FCS, and seeded into 6-well plates. Cells were harvested at days 5, 7, 9, 11 and 13, and culture supernatants and cell pellets were separately processed for determination of virus progeny yields and viral integration.

\section{HIV-1 production assay}

The yields of extracellular virus were evaluated in triplicate samples of culture supernatants of day $11 \mathrm{pi}$, using a CAp24 ELISA kit (Genscreen ULTRA HIV Ag-Ab, BioRad). Day-11 samples were also assayed for viral genome copy numbers, using COBAS $^{\circledR}$ AmpliPrep/COBAS TaqMan HIV-1 Test (Roche Diagnostics GmbH). Extracellular budding of virions was also monitored by syncytium formation observed in day-11 samples under an inverted microscope (Olympus).

\section{Gag protein assays}

Membrane-bound and particulate form of Gag proteins were determined in HIV-1-infected SupT1 cells subjected to cell fractionation. Triplicate cell samples of days 9 and 11 pi were lysed and extracted using the FractionPREPTM Cell Fractionation System (BioVision, Mountain View, $\mathrm{CA})$, following the manufacturer's instructions. The membrane fraction thus isolated was assayed for HIV-1 Gag protein content, using the CAp24 ELISA kit mentioned above, or SDS-polyacrylamide gel electrophoresis (SDSPAGE) and Western blotting. Proteins were denatured by heating to $100^{\circ} \mathrm{C}$ for $2 \mathrm{~min}$ in SDS- $\beta$-mercaptoethanolcontaining sample buffer, electrophoresed in SDS-containing 15\%-polyacrylamide gel [77], and then electrically transferred to a polyvinylidene-fluoride (PVDF) membrane. PVDF membranes were blocked with 5\% skimmed milk in PBS containing $0.5 \%$ Triton X-100, then probed with anti-CAp24 monoclonal antibody (mAb) G18, or anti-MAp17 mAb M48. Both G18 and M48 mAbs were laboratory-made (W. Kasinrerk; unpublished). Blots were developed using HRP-conjugated goat anti-mouse IgG antibody and TMB membrane peroxidase substrate. Extracellular virus-like particles (VLP) released by MLV GagPol-expressing GP2-293 cells were recovered by ultracentrifugation of the cell culture medium $[71,82]$, and VLP production estimated by SDS-PAGE of VLP pellets and Western blot analysis using rabbit polyclonal antibody to MLV-GagCAp30 protein (antibodies-online Inc., Atlanta, GA). Intracellular content of MLV Gag proteins was analyzed in the same manner, using the whole cell lysate.

\section{HIV-1 integration assay}

The number of viral genome copies integrated into the host DNA of control SupT1 or SupT1 expressing Gagspecific (Ank $\left.{ }^{\mathrm{GAG}} 1 \mathrm{D} 4\right)$ or irrelevant ankyrin (Ank ${ }^{\mathrm{A} 3} 2 \mathrm{D} 3$ ) was determined using a conventional Alu-gag qPCR assay $[83,84]$ with some modifications. The first-round of PCR was performed on cellular DNA, extracted using the High Pure PCR Template Preparation Kit (Roche, Mannheim, Germany). The sequences of the first round amplification 
primers were: Alu forward, 5'-GCC TCC CAA AGT GCT GGG ATT ACA G-3' [84], and HIV-1 gag reverse, 5'GTT CCT GCT ATG TCA CTT CC -3' [83]. The first round reactions were carried out in a volume of $25 \mu \mathrm{l}$ containing $2.5 \times$ master mix (5 PRIME, Gaithersburg, MD), using a standard protocol. The second-round of real-time quantitative PCR of RU5 was performed using $10 \mu \mathrm{l}$ of diluted (1:8) first-round amplicons. The sequences of primers were: R_FWD, 5'-TTA AGC CTC AAT AAA GCT TGC C-3'; and U5 _REV, 5'-GTT CGG GCG CCA CTG CTA GA-3', and the sequence of RU5 molecular beacon probe was 5'-FAM-CCA GAG TCA CAC AAC AGA CGG GCA CA-BBQ-3' [85]. The reactions were carried out in a final volume of $25 \mu \mathrm{l}$ containing $2 \times$ DyNAmo probe qPCR master mix (Finnzymes, Espoo, Finland), 400 nM RU5 (R_FWD) primer, 400 nM RU5 (U5 _REV) primer, and $140 \mathrm{nM}$ RU5 molecular beacon probe. The reactions were performed in a MJ Mini Thermal Cycler and MiniOpticon Real-Time PCR System (BioRad) with the following thermal program: 20 -sec hot start at $95^{\circ} \mathrm{C}$ followed by 50 cycles of denaturation at $95^{\circ} \mathrm{C}$ for $3 \mathrm{sec}$ and annealing and extension at $63^{\circ} \mathrm{C}$ for $30 \mathrm{sec}$. A primerprobe set, designed to quantify the copy number of the cellular gene glyceraldehyde 3-phosphate dehydrogenase $(G A P D H)$, was used to quantify the amount of DNA in each qPCR assay. The GAPDH primer sequences were as follows: GAPDH_FWD, 5'-GAA GGT GAA GGT CGG AGT C-3'; and GAPDH_REV, 5'-GAA GAT GGT GAT GGG ATT TC-3'. The GAPDHTM molecular beacon probe was designed to contain the following sequence: 5'FAM-CAA GCT TCC CGT TCT CAG CCT-BBQ-3'. The reactions were carried out as described above. Results were expressed as $\mathrm{Cts}$, i.e. the number of cycles ( $\mathrm{Cts}$ ) required for the fluorescence signal to cross the threshold value (cycle threshold). Control experiments for the inhibition of provirus integration in HIV-1-infected cells were carried out as follows. The HIV-1 integrase inhibitor Raltegravir $^{\mathrm{TM}}$ (RAL; Merck Sharp \& Dohme) was added at 0, 1,10 , and $100 \mathrm{nM}$, respectively, to SupT1 cell culture medium $24 \mathrm{~h}$ prior to HIV-1 infection [37]. SupT1 cells were then infected with $\mathrm{HIV}-1_{\mathrm{NL4}-3}$ at MOI 10 , and virus inoculum removed after $16 \mathrm{~h}$. Cells were washed three times with prewarmed, serum-free medium and resuspended in growth medium containing RAL at the abovementioned concentrations. Cells were divided (1:2) every second day to maintain a cell density of approximately $10^{6}$ cells per mL, and harvested at day-7 pi for Alu-gag and GAPDH qPCR assays. Cell viability in each sample was assayed using PrestoBlue Cell Viability Reagent (Invitrogen).

\section{HIV-1 gag gene sequencing}

Mock-infected or HIV-1-infected SupT1 cells (MOI 10) expressing $\mathrm{Myr}+\mathrm{Ank}{ }^{\mathrm{GAG}} 1 \mathrm{D} 4$ or $\mathrm{Myr}+\mathrm{Ank}^{\mathrm{A} 3}{ }_{2 \mathrm{D}}$, were harvested at day-13 pi. A four-step protocol was then applied. (i) Total viral RNA was isolated, using the High Pure Viral RNA kit (Roche Applied Science, Roche, Mannheim, Germany). (ii) The viral RNA thus obtained was reverse transcribed into cDNA, using the Transcriptor High Fidelity cDNA Synthesis Kit with anchored-oligo $(\mathrm{dT})_{18}$ primer (Roche). (iii) The single-stranded cDNA was then amplified, using a proof-reading PCR protocol (Phusion $^{\mathrm{TM}}$ High-Fidelity DNA Polymerase; Finnzymes, Espoo, Finland) and the following pair of p24-specific gene primers: FWD_p24 Nhe I, 5'-GAGGAGGAGGT GCTAGCCCTATAGTGCAGAACCTCCAG-3' and REV_p24 Kpn I, 5'-GAGGAGGAGCTGGTACCTTACAAAACTCTTGCTTTATGGCC-3'. (iv) The PCR products were purified using the GeneJETTM PCR purification kit (Fermentas International), and sequenced using standard DNA sequencing method (1st BASE Pte Ltd, Singapore).

\section{Confocal microscopy}

Aliquots of HIV-1-infected SupT1 cells $\left(1 \times 10^{6}\right.$ cells, MOI 10) were harvested on day $11 \mathrm{pi}$, washed with PBS, fixed in $4 \%$ formaldehyde in PBS, and permeabilized with $0.2 \%$ Triton X-100. After blocking with 10\% human AB serum for $30 \mathrm{~min}$ at room temperature, cells were incubated with $\mathrm{G} 18$ anti-CAp24 mAb at $37^{\circ} \mathrm{C}$ for $1 \mathrm{hr}$. After washing twice with PBS containing $1 \% \mathrm{BSA}$ and $\mathrm{NaN}_{3}$, cells were incubated with PE-conjugated polyclonal rabbit anti-mouse IgG F(ab') $)_{2}$ (Dako, Denmark), and nuclei counterstained with DAPI. Images were acquired using FluoView laser scanning confocal microscope (Olympus, FV1000; Olympus Optical, Japan).

\section{Conflict of interests}

The authors declare that they have no competing interests.

\section{Additional material}

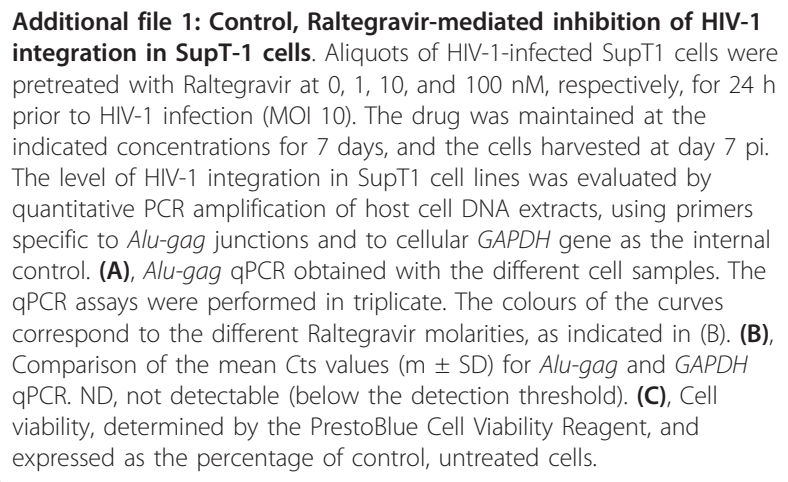

\section{Acknowledgements}

The work in Thailand was supported by the National Research University project under the Thailand's Office of the Commission on Higher Education. 
The authors also express their gratitude to the Thailand Research Fund, the Research Chair Grant of National Sciences and the Technology Development Agency and the Franco-Thai collaboration program. SN was supported by CHE-PhD-THAl scholarship from the Commission on Higher Education, Ministry of Education, Thailand, and the AMS-IRD URI-174 PHPT Franco-Thai Cooperation Program for High Education and Research. WK and SS were supported by The Royal Golden Jubilee PhD Program.

The work in France was supported by the Centre National de la Recherche Scientifique (CNRS), the French National Agency for Research on AIDS and Viral Hepatitis (Inserm-ANRS contract No 11344/2011-2013), the University of Lyon and the University of Paris-Sud. SSH is a scientist of the French Institute of Health and Medical Research (Institut National de la Santé et de la Recherche Médicale, Inserm) and the recipient of a Contrat d'Interface Inserm-Hospices Civils de Lyon (CIF-2008-2013). We deeply thank Supattara Suwanpairoj, Monique Martingay and Sylvie Farget for their precious technical help during the completion of this study.

\section{Author details}

'Division of Clinical Immunology, Department of Medical Technology, Faculty of Associated Medical Sciences, Chiang Mai University, Chiang Mai, Thailand 50200. ${ }^{2}$ Biomedical Technology Research Unit, National Center for GeneticEngineering and Biotechnology, National Science and Technology Development Agency at the Faculty of Associated Medical Sciences, Chiang Mai University, Chiang Mai 50200, Thailand. ${ }^{3}$ Institut de Biochimie et de Biophysique Moléculaire et Cellulaire (IBBMC) UMR-8619, Université de ParisSud et CNRS, Orsay Cedex 91405, France. ${ }^{4}$ University Lyon 1, 50, avenue Tony Garnier, 69366 Lyon Cedex 07, France. ${ }^{5}$ INRA UMR-754, Retrovirus and Comparative Pathology, 50, avenue Tony Garnier, 69366 Lyon Cedex 07, France.

\section{Authors' contributions}

Conceived and designed the experiments: SN AU SSH PB PM CT. Performed the experiments: SN AU MVL WK SS SSH PM. Analyzed the data: SN MVL WK SSH PM CT. Wrote the paper: SN SSH PB PM CT. All authors approved the submitted manuscript.

Received: 15 August 2011 Accepted: 20 February 2012 Published: 20 February 2012

\section{References}

1. Arora DR, Gautam V, Gill PS, Mishra N: Recent advances in antiretroviral therapy in HIV infection. J Indian Med Assoc 2010, 108:29-34.

2. Check E: Pioneering HIV treatment would use interference and gene therapy. Nature 2005, 437:601.

3. Luque F, Oya R, Macias D, Saniger L: Gene therapy for HIV-1 infection: are lethal genes a valuable tool? Cell Mol Biol 2005, 51:93-101.

4. Trkola A, Kuster H, Rusert P, Joos B, Fischer M, Leemann C, Manrique A, Huber M, Rehr M, Oxenius A, Weber R, Stiegler G, Vcelar B, Katinger H, Aceto L, Günthard HF: Delay of HIV-1 rebound after cessation of antiretroviral therapy through passive transfer of human neutralizing antibodies. Nat Med 2005, 11:615-622.

5. von Laer D, Hasselmann S, Hasselmann K: Gene therapy for HIV infection: what does it need to make it work? J Gene Med 2006, 8:658-667.

6. Gonzalo T, Clemente MI, Chonco L, Weber ND, Diaz L, Serramia MJ, Gras R, Ortega P, de la Mata FJ, Gomez R, Lopez-Fernández LA, MuñozFernández MA, Jiménez JL: Gene therapy in HIV-infected cells to decrease viral impact by using an alternative delivery method. Chem Med Chem 2010, 5:921-929.

7. Joseph A, Zheng JH, Chen K, Dutta M, Chen C, Stiegler G, Kunert R, Follenzi A, Goldstein H: Inhibition of in vivo HIV infection in humanized mice by gene therapy of human hematopoietic stem cells with a lentiviral vector encoding a broadly neutralizing anti-HIV antibody. J Virol 2010, 84:6645-6653.

8. Kitchen SG, Shimizu S, An DS: Stem cell-based anti-HIV gene therapy. Virology 2011, 411:260-272.

9. Berkhout B: Towards a durable anti-HIV gene therapy based on RNA interference. Ann NY Acad Sci 2009, 1175:3-14

10. Rossi JJ, June CH, Kohn DB: Genetic therapies against HIV. Nat Biotech 2007, 25:1444-1454.

11. Wheeler YY, Chen SY, Sane DC: Intrabody and intrakine strategies for molecular therapy. Mol Ther 8:355-66 2003, 8:355-366.
12. Binz HK, Amstutz $P$, Kohl A, Stumpp MT, Briand C, Forrer P, Grutter MG, Pluckthun A: High-affinity binders selected from designed ankyrin repeat protein libraries. Nat Biotechnol 2004, 22:575-582.

13. Binz HK, Amstutz $P$, Pluckthun $A$ : Engineering novel binding proteins from nonimmunoglobulin domains. Nat Biotech 2005, 23:1257-1268.

14. Binz HK, Pluckthun A: Engineered proteins as specific binding reagents. Curr Opin Biotechnol 2005, 16:459-469.

15. Guglielmi L, Martineau P: Expression of single-chain Fv fragments in $E$. coli cytoplasm. Methods Mol Biol 2009, 562:215-224.

16. Zhao JX, Yang L, Gu ZN, Chen HQ, Tian FW, Chen YQ, Zhang H, Chen W: Stabilization of the single-chain fragment variable by an interdomain disulfide bond and its effect on antibody affinity. Int J Mol Sci 2010, 12:1-11.

17. Hey T, Fiedler E, Rudolph R, Fiedler M: Artificial, non-antibody binding proteins for pharmaceutical and industrial applications. Trends Biotechnol 2005, 23:514-522.

18. Lofblom J, Frejd FY, Stahl S: Non-immunoglobulin based protein scaffolds. Curr Opin Biotechnol 2011, 22:1-6.

19. Nygren $P A$, Uhlen $M$ : Scaffolds for engineering novel binding sites in proteins. Curr Opin Struct Biol 1997, 7:463-469.

20. Li J, Mahajan A, Tsai MD: Ankyrin repeat: a unique motif mediating protein-protein interactions. Biochemistry 2006, 45:15168-15178.

21. Mosavi LK, Cammett TJ, Desrosiers DC, Peng ZY: The ankyrin repeat as molecular architecture for protein recognition. Protein Sci 2004, 13:1435-14448.

22. Andrade MA, Perez-Iratxeta C, Ponti CP: Protein repeats: structures, functions, and evolution. J Struct Biol 2001, 134:117-131.

23. Binz HK, Stumpp MT, Forrer P, Amstutz P, Pluckthun A: Designing repeat proteins: well-expressed, soluble and stable proteins from combinatorial libraries of consensus ankyrin repeat proteins. J Mol Biol 2003, 332:489-503.

24. Boersma YL, Plückthun A: DARPins and other repeat protein scaffolds: advances in engineering and applications. Curr Opin Biotechnol 2011, 22:849-857.

25. Sedgwick SG, Smerdon SJ: The ankyrin repeat: a diversity of interactions on a common structural framework. Trends Biochem Sci 1999, 24:311-316.

26. Stumpp MT, Amstutz P: DARPins: a true alternative to antibodies. Curr Opin Drug Discov Devel 2007, 10:153-159.

27. Stumpp MT, Binz HK, Amstutz P: DARPins: a new generation of protein therapeutics. Drug Discov Today 2008, 13:695-701.

28. Schweizer $A$, Rusert $P$, Berlinger $L$, Ruprecht $C R$, Mann $A$, Corthésy $S$, Turville SG, Aravantinou M, Fischer M, Robbiani M, Amstutz P, Trkola A: CD4-specific designed ankyrin repeat proteins are novel potent HIV entry inhibitors with unique characteristics. PLoS Pathog 2008, 4 : e1000109.

29. Schweizer A, Roschitzki-Voser H, Amstutz P, Briand C, Gulotti-Georgieva M, Prenosil E, Binz HK, Capitani G, Baici A, Pluckthun A, Grutter MG: Inhibition of caspase- 2 by a designed ankyrin repeat protein: specificity, structure, and inhibition mechanism. Structure 2007, 15:625-636.

30. Zahnd C, Wyler E, Schwenk JM, Steiner D, Lawrence MC, McKern NM, Pecorari F, Ward CW, Joos TO, Plückthun A: A designed ankyrin repeat protein evolved to picomolar affinity to Her2. J Mol Biol 2007, 369:1015-1028.

31. Münch RC, Mühlebach MD, Schaser T, Kneissl S, Jost C, Plückthun A, Cichutek K, Buchholz CJ: DARPins: an efficient targeting domain for lentiviral vectors. Mol Ther 2011, 19:686-693.

32. Huber $T$, Steiner $D$, Rothlisberger D, Pluckthun A: In vitro selection and characterization of DARPins and Fab fragments for the co-crystallization of membrane proteins: the Na+-citrate symporter $\mathrm{CitS}$ as an example. $J$ Struct Biol 2007, 159:206-221.

33. Urvoas A, Guellouz A, Valerio-Lepiniec M, Graille M, Durand D, Desravines DC, van Tilbeurgh H, Desmadril M, Minard P: Design, production and molecular structure of a new family of artificial alphahelicoidal repeat proteins (alphaRep) based on thermostable HEAT-like repeats. J Mol Biol 2010, 404:307-327.

34. Hong SS, Boulanger P: Protein ligands of human Adenovirus type 2 outer capsid identified by biopanning of a phage-displayed peptide library on separate domains of WT and mutant penton capsomers. EMBO J 1995, 14:4714-4727.

35. Hong SS, Karayan L, Tournier J, Curiel DT, Boulanger PA: Adenovirus type 5 fiber knob binds to MHC class I alpha2 domain at the surface of human epithelial and B lymphoblastoid cells. EMBO J 1997, 16:2294-2306. 
36. Carrière C, Gay B, Chazal N, Morin N, Boulanger P: Sequence requirement for encapsidation of deletion mutants and chimeras of human immunodeficiency virus type $1 \mathrm{Gag}$ precursor into retrovirus-like particles. J Virol 1995, 69:2366-2377.

37. Delelis O, Malet I, Na L, Tchertanov L, Calvez V, Marcelin AG, Subra F, Deprez E, Mouscadet JF: The G140S mutation in HIV integrases from raltegravir-resistant patients rescues catalytic defect due to the resistance Q148H mutation. Nucleic Acids Res 2009, 37:1193-1201.

38. Vu HN, Ramsey JD, Pack DW: Engineering of a stable retroviral gene delivery vector by directed evolution. Mol Ther 2008, 16:308-314

39. Rakotobe D, Tardy J-C, Andre P, Hong SS, Darlix J-L, Boulanger P: Human Polycomb group EED protein negatively affects HIV-1 assembly and release. Retrovirology 2007, 4:37.

40. Wensing AM, Boucher CA: Worldwide transmission of drug-resistant HIV. AIDS Rev 2003, 5:140-155.

41. Adamson CS, Freed EO: Novel approaches to inhibiting HIV-1 replication. Antiviral Res 2010, 85:119-141.

42. Greene WC, Debyser Z, Ikeda Y, Freed EO, Stephens E, Yonemoto W, Buckheit RW, Esté JA, Cihlar T: Novel targets for HIV therapy. Antiviral Res 2008, 80:251-265.

43. Muriaux D, Darlix J-L, Cimarelli A: Targeting the assembly of the human immunodeficiency virus type 1. Current Pharmaceutical Design 2004, 10:3725-3739.

44. Sticht J, Humbert M, Findlow S, Bodem J, Muller B, Dietrich U, Werner J, Kräusslich H-G: A peptide inhibitor of HIV-1 assembly in vitro. Nat Struct Mol Biol 2005, 12:671-677.

45. Tang C, Loeliger E, Kinde I, Kyere S, Mayo K, Barklis E, Sun Y, Huang M, Summers MF: Antiviral inhibition of the HIV-1 capsid protein. $J \mathrm{Mol}$ Biol 2003, 327:1013-1020.

46. Ternois F, Sticht J, Duquerroy S, Kräusslich H-G: The HIV-1 capsid potein Cterminal domain in complex with a virus assembly inhibitor. Nat Struct Mol Biol 2005, 12:678-682.

47. Waheed AA, Freed EO: Peptide inhibitors of HIV-1 egress. ACS Chem Biol 2008, 3:745-747.

48. Waheed AA, Ono A, Freed EO: Methods for the study of HIV-1 assembly. Methods Mol Biol 2009, 485:163-184.

49. Wainberg MA: Perspectives on antiviral drug development. Antiviral Res 2009, 81:1-5.

50. Woods MW, Kelly JN, Hattlmann CJ, Tong JGK, Xu LS, Coleman MD, Quest GR, Smiley JR, Bar SD: Human HERC5 restricts an early stage of HIV1 assembly by a mechanism correlating with the ISGylation of Gag. Retrovirology 2011, 8:95.

51. Poole E, Strappe P, Mok HP, Hicks R, Lever AM: HIV-1 Gag-RNA interaction occurs at a perinuclear/centrosomal site; analysis by confocal microscopy and FRET. Traffic 2005, 6:741-755.

52. Anderson EC, Lever AM: Human immunodeficiency virus type $1 \mathrm{Gag}$ polyprotein modulates its own translation. J Virol 2006, 80:10478-10486.

53. Ricci EP, Soto Rifo R, Herbreteau CH, Decimo D, Ohlmann T: Lentiviral RNAs can use different mechanisms for translation initiation. Biochem Soc Trans 2008, 36:690-693.

54. Alfadhli A, Dhenub TC, Still A, Barklis E: Analysis of human immunodeficiency virus type $1 \mathrm{Gag}$ dimerization-induced assembly. $J$ Virol 2005, 79:14498-14506.

55. Jouvenet N, Simon SM, Bieniasz PD: Imaging the interaction of HIV-1 genomes and Gag during assembly of individual viral particles. Proc Natl Acad Sci USA 106:19114-19119.

56. Kutluay SB, Bieniasz PD: Analysis of the initiating events in HIV-1 particle assembly and genome packaging. PLoS Pathogens 2010, 6: e1001200.

57. Lindwasser OW, Resh MD: Myristoylation as a target for inhibiting HIV assembly: unsaturated fatty acids block viral budding. Proc Natl Acad Sci USA 2002, 99:13037-13042.

58. Ganser-Pornillos BK, Cheng A, Yeager M: Structure of full-length HIV-1 CA: a model for the mature capsid lattice. Cell 2007, 131:70-79.

59. Ganser-Pornillos BK, von Schwedler UK, Stray KM, Aiken C, Sundquist WI: Assembly properties of the human immunodeficiency virus type 1 CA protein. J Virol 2004, 78:2545-2552.

60. Ganser-Pornillos BK, Yeager M, Sundquist WI: The structural biology of HIV assembly. Curr Opin Struct Biol 2008, 18:203-217.

61. Colgan J, Yuan HE, Franke EK, Luban J: Binding of the human immunodeficiency virus type $1 \mathrm{Gag}$ polyprotein to cyclophilin A is mediated by the central region of capsid and requires Gag dimerization. J Virol 1996, 70:4299-4310.

62. Dorfman T, Weimann A, Borsetti A, Walsh CT, Göttlinger HG: Active-site residues of cyclophilin $A$ are crucial for its incorporation into human immunodeficiency virus type 1 virions. J Virol 1997, 71:7110-7113.

63. Zhao Y, Chen Y, Schutkowski M, Fischer G, Ke H: Cyclophilin A complexed with a fragment of HIV-1 gag protein: insights into HIV-1 infectious activity. Structure 1997, 5:139-146

64. Briant L, Gay B, Devaux C, Chazal N: HIV-1 assembly, release and maturation. WJA 2011, 1:111-130.

65. Cimarelli A, Darlix J-L: Assembling the human immunodeficiency virus type 1. Cell Mol Life Sci 2002, 59:1166-1184.

66. Darlix JL, Cristofari G, Rau M, Péchoux C, Berthoux L, Roques B: Nucleocapsid protein of human immunodeficiency virus as a model protein with chaperoning functions and as a target for antiviral drugs. Adv Pharmacol 2000, 48:345-372.

67. Ma YM, Vogt VM: Rous sarcoma virus Gag protein-oligonucleotide interaction suggests a critical role for protein dimer formation in assembly. J Virol 2002, , 76: 5452-5462.

68. Ma YM, Vogt VM: Nucleic acid binding-induced Gag dimerization in the assembly of Rous Sarcoma Virus particles in vitro. J Virol 2004, 78:52-60.

69. Gamble TR, Yoo S, Vajdos FF, von Schwedler UK, Worthylake DK, Wang H, McCutcheon JP, Sundquist WI, Hill CP: Structure of the carboxyl-terminal dimerization domain of the HIV-1 capsid protein. Science 1997, 278:849-853.

70. Ganser BK, Li S, Klishko VY, Finch JT, Sundquist Wl: Assembly and analysis of conical models for the HIV-1 core. Science 1999, 283:80-83.

71. DaFonseca S, Blommaert A, Coric P, Hong SS, Bouaziz S, Boulanger P: The 3-O-(3', 3'-dimethylsuccinyl) derivative of betulinic acid (DSB) inhibits the assembly of virus-like particles in HIV-1 Gag precursor-expressing cells. Antiviral Ther 2007, 12:1185-1203.

72. Hong SS, Boulanger P: Self-assembly-defective dominant mutants of HIV1 Gag phenotypically expressed in baculovirus-infected cells. J Virol 1993, 67:2787-2798.

73. Huvent I, Hong SS, Fournier C, Gay B, Tournier J, Carriere C, Courcoul M, Vigne R, Spire B, Boulanger P: Interaction and co-encapsidation of HIV-1 Vif and Gag recombinant proteins. J Gen Virol 1998, 79:1069-1081.

74. Royer M, Hong SS, Gay B, Cerutti M, Boulanger P: Expression and extracellular release of human immunodeficiency virus type $1 \mathrm{Gag}$ precursors by recombinant baculovirus-infected cells. J Virol 1992, 66:3230-3235.

75. Nangola S, Minard P, Tayapiwatana C: Appraisal of translocation pathways for displaying ankyrin repeat protein on phage particles. Protein Expr Purif 2010, 74:156-161.

76. Steiner D, Forrer P, Pluckthun A: Efficient selection of DARPins with subnanomolar affinities using SRP phage display. J Mol Biol 2008, 382:1211-1227.

77. Kitidee K, Nangola S, Gonzalez G, Boulanger P, Tayapiwatana C, Hong SS: Baculovirus display of single chain antibody (scFv) using a novel signal peptide. BMC Biotechnol 2010, 10:80.

78. Sakkhachornphop S, Jiranusornkul S, Kodchakorn K, Nangola S, Sirisanthana T, Tayapiwatana C: Designed zinc finger protein interacting with the HIV-1 integrase recognition sequence at 2-LTR-circle junctions. Protein Sci 2009, 18:2219-2230.

79. Cressey R, Pimpa S, Chewaskulyong B, Lertprasertsuke N, Saeteng S, Tayapiwatana C, Kasinrerk W: Simplified approaches for the development of an ELISA to detect circulating autoantibodies to p53 in cancer patients. BMC Biotechnology 2008, 8:16.

80. Nicaise M, Valerio-Lepiniec M, Minard P, Desmadril M: Affinity transfer by CDR grafting on a nonimmunoglobulin scaffold. Protein Sci 2004, 13:1882-1891.

81. Pata S, Tayapiwatana C, Kasinrerk W: Three different immunogen preparation strategies for production of CD4 monoclonal antibodies. Hybridoma 2009, 28:159-165.

82. Gonzalez G, DaFonseca S, Errazuriz E, Coric P, Souquet F, Turcaud S, Boulanger P, Bouaziz S, Hong SS: Characterization of a novel type of HIV1 particle assembly inhibitor using a quantitative luciferase-Vpr packaging-based assay. PLoS One 2011, 6:e27234.

83. Agosto LM, Yu JJ, Dai J, Kaletsky R, Monie D, O'Doherty U: HIV-1 integrates into resting $\mathrm{CD} 4+\mathrm{T}$ cells even at low inoculums as demonstrated with an improved assay for HIV-1 integration. Virology 2007, 368:60-72. 
84. O'Doherty U, Swiggard WJ, Jeyakumar D, McGain D, Malim MH: A sensitive, quantitative assay for human immunodeficiency virus type 1 integration. J Virol 2002, 76:10942-10950.

85. Liszewski MK, Yu JJ, O'Doherty U: Detecting HIV-1 integration by repetitive-sampling Alu-gag PCR. Methods 2009, 47:254-260.

doi:10.1186/1742-4690-9-17

Cite this article as: Nangola et al.: Antiviral activity of recombinant ankyrin targeted to the capsid domain of HIV-1 Gag polyprotein. Retrovirology 2012 9:17.

Submit your next manuscript to BioMed Central and take full advantage of:

- Convenient online submission

- Thorough peer review

- No space constraints or color figure charges

- Immediate publication on acceptance

- Inclusion in PubMed, CAS, Scopus and Google Scholar

- Research which is freely available for redistribution

Submit your manuscript at www.biomedcentral.com/submit
() Biomed Central 